


\section{About IDS}

The Institute of Development Studies is one of the world's leading charities for research, teaching and communications on international development. Founded in 1966, the Institute enjoys an international reputation based on the quality of its work and the rigour with which it applies academic skills to real world challenges. Its purpose is to understand and explain the world, and to try to change it - to influence as well as to inform.

IDS hosts five dynamic research programmes, five popular postgraduate courses, and a family of worldclass web-based knowledge services. These three spheres are integrated in a unique combination - as a development knowledge hub, IDS is connected into and is a convenor of networks throughout the world.

The Institute is home to approximately 80 researchers, 50 knowledge services staff, 50 support staff and about 150 students at any one time. But the IDS community extends far beyond, encompassing an extensive network of partners, former staff and students across the development community worldwide.

(D) Institute of Development Studies

For further information on IDS publications and for a free catalogue, contact: IDS Communication Unit

Institute of Development Studies

at the University of Sussex

Brighton BN1 9RE, UK

Tel: $+44(0) 1273915637$

Fax: +44 (0) 1273621202

E-mail: bookshop@ids.ac.uk

Web: www.ids.ac.uk/ids/bookshop

IDS is a charitable company, limited by guarantee and registered in England (No. 877338) 


\section{IDS RESEARCH REPORT 64}

\section{Security Systems in \\ Francophone Africa}

Niagalé Bagayoko

May 2010 
Security Systems in Francophone Africa

Niagalé Bagayoko

IDS Research Report 64

First published by the Institute of Development Studies in May 2010

Cover photo: Rebecca Blackwell/Associated Press

Photo caption: A Senegalese police officer stands guard alongside an unfinished sculpture portraying the map of Africa by Ousmane Sembene, in Dakar.

(c) Institute of Development Studies 2010

ISSN 0141-1314 ISBN 9781858649226

A catalogue record for this publication is available from the British Library.

All rights reserved. Reproduction, copy, transmission, or translation of any part of this publication may

be made only under the following conditions:

- with the prior permission of the publisher; or

- with a licence from the Copyright Licensing Agency Ltd., 90 Tottenham Court Road, London W1P 9HE, UK,

or from another national licensing agency; or

- under the terms set out below.

This publication is copyright, but may be reproduced by any method without fee for teaching or nonprofit purposes, but not for resale. Formal permission is required for all such uses, but normally will be granted immediately. For copying in any other circumstances, or for re-use in other publications, or for translation or adaptation, prior written permission must be obtained from the publisher and a fee may be payable.

Available from:

Communications Unit

Institute of Development Studies

at the University of Sussex

Brighton BN1 9RE, UK

Tel: +44 (0) 1273915637

Fax: +44 (0) 1273621202

E-mail: bookshop@ids.ac.uk

Web: www.ids.ac.uk/ids/bookshop

Typeset by Barbara Cheney, Bath, UK. Printed by Nexus, Brighton UK.

IDS is a charitable company limited by guarantee and registered in England (No. 877338). 


\section{Summary}

This research report is a broad-based study that seeks to understand the structural and developmental processes that characterise the security sector in Francophone Africa.

Although each country has a distinct political history and tradition, similarities in the security apparatus, rooted in its inheritance from the colonial and post-colonial periods, can be found between Francophone countries in Africa. In the former French colonies, there are similarities to the French security system which are very strong on the normative side, such as the legal and institutional framework or the defence and security actors. However, even if these Francophone African countries borrow a lot from an originally French security system in terms of the institutional design of their security apparatus, they deviate considerably from it in terms of daily practice.

The issue at stake in this paper is to highlight the kind of institutional framework prevailing in this set of countries and the specific considerations that international assistance will have to take into account. The paper also analyses briefly the difference between Anglophone and Francophone security systems.

Finally, it makes some recommendations that might assist the security sector reform policy agenda and donor and recipient responses to the security challenges faced in Francophone Africa.

Keywords: Security Sector Reform (SSR); Francophone Africa; armed forces; Military; Police forces

Niagalé Bagayoko is a Fellow of IDS. She is a political scientist with a doctorate from the University of Paris. She has published widely, including a 2003 book on US and French security policies in Africa (Afrique: Les Stratégies Française et Américaine) and three other volumes. She is currently researching sector reform in Francophone African countries and has led field research in the Central African Republic, Cameroon, Mali and Senegal. She has also studied interagency and multilateral processes in post-conflict environments; sub-regional security mechanisms in West Africa (ECOWAS); and African conflict-management mechanisms.

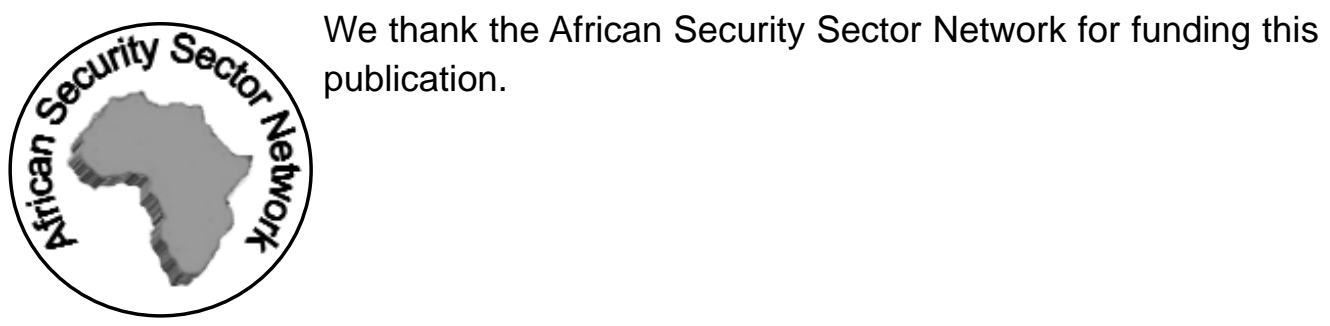


IDS RESEARCH REPORT 64 


\section{Contents}

Summary, keywords, author note 3

$\begin{array}{ll}\text { Acronyms } & 7\end{array}$

1 Introduction 11

2 Heritage from the colonial and post-colonial periods 13

2.1 France and its African colonies 13

2.2 The 'special relationship' between France and Africa after independence15

3 General overview of the security apparatus in Francophone African states

3.1 Constitutional frameworks in the former French Colonies 17

3.2 Constitutional provisions relating to security in the former French African colonies

3.2.1 Power sharing between the President and the government

3.2.2 Legislative mandate: parliamentarian control and oversight ${ }^{1}$ of the security services

3.2.3 Specific provisions against praetorianism 20

3.2.4 Conscription and military service 21

3.2.5 The model of a developmental army 22

3.2.6 Administrative and territorial organisation in former French African colonies

3.3 Democratic versus authoritarian regimes 23

3.4 Institutional organisation of the security apparatus 24

3.4.1 National security organisations 24

3.4.2 The Minister of Defence 25

3.4.3 The armed forces in former French colonies 26

3.4.4 Police forces in Francophone Africa 30

3.4.5 The intelligence services $\quad 42$

3.4.6 The Paramilitary security services: customs 43

3.4.7 Private security companies 44

3.4.8 Vigilante groups and non-state security actors $\quad 47$

3.4.9 The legal and institutional environment of budgeting 48

3.5 Research on Security Sector Reform (SSR) in Francophone Africa 52

3.6 Military schools and police academies in Francophone Africa 53

1 In SSR terminology, the word oversight relates to 'the concept of separate branches of government or agencies exercising authority over one another'. 
4 Comparison between security systems in Francophone and Anglophone Africa

4.1 Security reforms in Francophone and Anglophone Africa 55

4.1.1 Legacy of the colonial and post-colonial order 57

4.1.2 The armed forces 61

4.1.3 Police forces 63

4.1.4 The intelligence services $\quad 64$

4.1.5 Funding provisions 65

4.1.6 Research on Security Sector Reform (SSR) 65

4.1.7 Military schools and police academies in Anglophone Africa 66

5 Recommendations 66

6 Conclusion $\quad 69$

Annex: Military schools in Francophone Africa $\quad 70$

$\begin{array}{ll}\text { References } & 71\end{array}$ 


\section{Acronyms}

\begin{tabular}{|c|c|}
\hline ACS & American Colonisation Society \\
\hline AEF & Afrique Equatoriale Française - Equatorial French Africa \\
\hline AFL & Armed Forces of Liberia \\
\hline AOF & Afrique Occidentale Française - French Western Africa \\
\hline ASDR & African Security Dialogue and Research \\
\hline ASSN & African Security Sector Network \\
\hline $\mathrm{AU}$ & African Union \\
\hline BDP & Botswana Democratic Party \\
\hline BMATT & British Military Advisory Training Team \\
\hline BWAFF & British West Africa Frontier Force \\
\hline CAR & Central African Republic \\
\hline CDD & Centre for Democracy and Development \\
\hline $\begin{array}{l}\text { CEDEAO/ } \\
\text { ECOWAS }\end{array}$ & $\begin{array}{l}\text { Communauté économique des Etats d'Afrique de l'Ouest - } \\
\text { Economic Community of West African States }\end{array}$ \\
\hline CEEAC/ECCAS & $\begin{array}{l}\text { Communauté économique des Etats d'Afrique centrale - } \\
\text { Economic Community of Central African States }\end{array}$ \\
\hline CEMA & Chef d'état-major - Chief of Staff \\
\hline CEMAC & $\begin{array}{l}\text { Communauté économique et monétaire d'Afrique centrale - } \\
\text { Central Africa Economic and Monetary Community }\end{array}$ \\
\hline CIFDI & $\begin{array}{l}\text { Carrefour International Francophone de Documentation et } \\
\text { d'Information }\end{array}$ \\
\hline CPRD & Centre for Policy Research and Dialogue \\
\hline CRS & $\begin{array}{l}\text { Compagnies Républicaines de Sécurité - Companies for } \\
\text { Republican Security }\end{array}$ \\
\hline CSC & Command and Staff School \\
\hline DAC & Development Assistance Committee \\
\hline DFID & Department for International Development \\
\hline DGCE & $\begin{array}{l}\text { Direction générale de la sécurité extérieure - Directorate for } \\
\text { External Security }\end{array}$ \\
\hline DGGN & $\begin{array}{l}\text { Direction/Directeur general(e) de la gendarmerie nationale - } \\
\text { General Directorate or Head of the National Gendarmerie }\end{array}$ \\
\hline
\end{tabular}




\begin{tabular}{|c|c|}
\hline DGPN & $\begin{array}{l}\text { Direction/Directeur General(e) de la Police Nationale - General } \\
\text { Directorate or Head of the National Police }\end{array}$ \\
\hline DOT & $\begin{array}{l}\text { Défense opérationnelle du territoire - Operational Defence of } \\
\text { the Territory }\end{array}$ \\
\hline DPS & Department of Protection and Security \\
\hline DRC & Democratic Republic of Congo \\
\hline DRM & $\begin{array}{l}\text { Direction du renseignement militaire - Directorate for Military } \\
\text { Intelligence }\end{array}$ \\
\hline DST & $\begin{array}{l}\text { Direction de la Surveillance du Territoire - Surveillance of the } \\
\text { Territory Directorate }\end{array}$ \\
\hline ECOWAS & Economic Community of West African States \\
\hline $\mathrm{EHC}$ & Earthwind Holding Corporation \\
\hline ENVR & $\begin{array}{l}\text { Ecoles Nationales à Vocation Régionale - National Schools } \\
\text { with regional vocation }\end{array}$ \\
\hline ESDP & European Security and Defence Policy \\
\hline FAC & Forces armées congolaises - Congolese armed forces \\
\hline $\mathrm{FANCl}$ & Forces armées de Côte d'Ivoire - Ivory Coast Armed Forces \\
\hline FAR & $\begin{array}{l}\text { Forces armées rwandaises - Rwandan armed forces } \\
\text { (disbanded in 1994) }\end{array}$ \\
\hline FARDC & Forces armées de RDC - Congolese Armed forces \\
\hline FAZ & Forces armées zaïroises - armed forces of former Zaire \\
\hline FNIS & National Intervention and Security Force \\
\hline GIGN & $\begin{array}{l}\text { Groupement D'Intervention de la Gendarmerie Nationale - } \\
\text { National Gendarmerie Intervention Groups }\end{array}$ \\
\hline GMRRR & $\begin{array}{l}\text { Groupe de réflexion mixte sur la réforme et la réorganisation } \\
\text { de la PNC - Contact Group on the reform and reorganisation of } \\
\text { the Congolese National Police }\end{array}$ \\
\hline GSSP & $\begin{array}{l}\text { Groupement special pour la sécurité présidentielle - } \\
\text { Presidential Guard in RDC, recently replaced by the RG } \\
\text { (Republican Guard) }\end{array}$ \\
\hline IGP & Inspector General of Police \\
\hline IIC & International Instruction Corps \\
\hline IMATT & International Military Advisory Training Team \\
\hline IMF & International Monetary Fund \\
\hline ISS & Institute for Security Studies \\
\hline
\end{tabular}




\begin{tabular}{|c|c|}
\hline KAIPTC & Kofi Annan International Peacekeeping and Training Centre \\
\hline LFF & Liberia Frontier Force \\
\hline MDA & Ministries, Departments and Agencies \\
\hline MoD & Ministry of Defence \\
\hline MoF & Ministry of Finance \\
\hline MONUC & $\begin{array}{l}\text { Mission des Nations Unies en RDC - United Nations Mission in } \\
\text { DRC }\end{array}$ \\
\hline NATO & North Atlantic Treaty Organisation \\
\hline NCACC & National Conventional Arms Control Committee \\
\hline NDI & National Democratic Institute \\
\hline NICOC & National Intelligence Coordinating Committee \\
\hline NSC & National Security Council \\
\hline OAU & Libreville Convention for the Elimination of Mercenarism in Africa \\
\hline OECD & Organisation for Economic Co-operation and Development \\
\hline OFPA & Observatory of the African Public services \\
\hline OGA & $\begin{array}{l}\text { Organisation des Gendarmeries Africaines - African } \\
\text { Gendarmeries Organisation }\end{array}$ \\
\hline PEF & Police Equipment Fund \\
\hline PEM & Public expenditure management \\
\hline PG & Presidental Guard \\
\hline PMC & Private Military Companies \\
\hline PMU & Police Mobile Unit \\
\hline PNC & Police Nationale Congolaise - Congolese National Police \\
\hline PSC & Private Security Company \\
\hline RCA/CAR & Central African Republic \\
\hline REC & Regional economic communities \\
\hline RFMA & Regulation of Foreign Military Assistance \\
\hline RG & Renseignements Généraux - Internal Intelligence services \\
\hline RRF & rapid reaction force \\
\hline SADESM & Southern African Defence and Security Management Network \\
\hline SADF & South African Defence Forces \\
\hline
\end{tabular}


SAS

SGDN

SRIC

SSR

SST

SSG

TST

UEMOA

UN

UPI

WP
Security and Advisory Service

Sécretariat Général de la Défense Nationale - General Secretariat of National Defence

Security Research and Information Centre

Security Sector Reform

Security Sector Transformation

Security Sector Governance

Territorial Service Troops

Union économique et monétaire ouest-africaine - Economic and Monetary Union of West Africa

United Nations

Unité de Police Integrée - Integrated Police Unit

Working Paper 


\section{Introduction}

This research report is a broad-based study that seeks to understand the structural and developmental processes that characterise the security sector in Francophone Africa. It aims to provide a systematic overview and understanding of the actors involved, the structures, and how security systems function: former French territories (Benin, Burkina Faso, Cameroon, Chad, Congo, Côte d'Ivoire, Central Africa, Gabon, Guinea, Mali, Niger, Senegal and Togo) are reviewed here. Although each country has a distinct political history and tradition, similarities in the security apparatus, rooted in its inheritance from the colonial and post-colonial periods, can be found between countries that belong to Francophone Africa.

Going beyond the various historical, constitutional, legal and regulatory instruments that serve as the framework for security sector governance, this study aims to provide a critical perspective on the Francophone security sector in the present day, by raising issues that can contribute to a better understanding of the challenges that it faces. The purpose is to map and analyse how security institutions work in Francophone Africa and how the different actors (security providers as well as overseeing actors) relate to each other. In addition to enquiring into the respective missions of the different security forces, this study thus provides information on the role played by the different institutions; their structure, organisation and culture; their mutual relationships and the kind of control exercised on them. The sphere of activities to be covered is wide, and thus a certain selectivity has been used in order to capture the general dynamics, the actors, the structures and the organisation that shapes the security sector.

Little about the security sector in Francophone Africa has been documented or written down. Carrying out documentary research into the institutional security development in Francophone Africa is therefore a real challenge: there is little information and few materials - either primary or secondary sources, that are available in the public domain. Only a few states have compiled the statutory rules of their Public service, ${ }^{2}$ and texts relating to the special statute that characterise most of the defence and security forces in Francophone African states are unavailable. The same applies to all the texts which establish new democratic institutions: even if an official journal exists, its publication has often become increasingly erratic, or has been taken out of circulation altogether. The same goes for the national conferences whose minutes have currently become difficult to obtain. As a consequence, priority must be given to European or North American research or documentation centres when carrying out documentary research into the security sector of an African Francophone country. This report is

2 The term 'public service' here refers to the staff employed by national governments to implement public policies. Burundi, Mali, Rwanda and Senegal are the only French speaking states to have carried out this sort of work. Based in Cotonou, the Observatory of the African Public services (OFPA) has undertaken to gather the texts that relate to African Public services (OFPA 1995); see www.ofpa.net (accessed 7 March 2010). However, there are still a lot of gaps on the data collected to date. The most useful data can be found on the website of the Centre Etat de droit (Institut d'Etudes politiques de Bordeaux): www.etat.sciencespobordeaux.fr (accessed 7 March 2010). Finally, some information is also usefully provided by the Carrefour International Francophone de Documentation et d'Information (CIFDI). 
mostly based on a literature review of the scarce existing resources. In addition, data was collected on the ground during field trips to the Central African Republic (CAR), Cameroon, Mali and Senegal that has been very useful.

To adequately deal with the problems of the security sector in Francophone Africa, and to appreciate what its assessment needs are, this paper is divided into six sections:

- Firstly, it starts with a general historical overview of the Francophone security sector in terms of its origins and development, from its inception in the colonial period to independence;

- Second, constitutional provisions, as well as the other legislative instruments regulating the security sector (principles, rules, and actors including the role of the Parliaments), are reviewed;

- Third, there is an outline of the structural organisation and the role and missions of the defence and security forces (special units of the armed forces, police forces, municipal police, gendarmerie forces; intelligence services; paramilitary forces such as customs and private security companies);

- Fourth, funding provisions are outlined;

- Fifth, the military schools and police academies which can be found in Francophone Africa are presented;

- Sixth, the differences between Anglophone and Francophone Security Systems are analysed.

Finally, the paper draws some conclusions and makes recommendations that might assist the security sector reform (SSR) policy agenda, and donor and recipient responses to the security challenges faced in Francophone environments. 


\section{Heritage from the colonial and post-colonial periods}

There is a lot of coherence between the former French colonies reviewed in this research report, which were all governed in the same way. In all Francophone African states, the security system is a direct heritage from the structures put in place under colonial rule and maintained, from the 1960s onwards, by independent governments.

\subsection{France and its African colonies}

The Francophone African defence apparatus originates from French colonial troops (Troupes Coloniales). From 1822 to 1900, both French and indigenous troops were initially designated as Marines (Troupes de Marine) and administered by the Navy Ministry, even if they were mostly made up of infantry, and also included artillery units. Their insignia was a badge with an anchor that continued to be worn after the Troupes de Marine became the Colonial Troops in 1900. The French colonial troops are different from the Armée Coloniale which include North African regiments such as the Zouave, the Saphis, the Goumiers, and the Foreign Legion. However, some African troops (Goumiers guard in Mali, Saphis in Senegal) were part of both structures. The French colonial troops were divided into:

- The French long service volunteers (French troops from France serving in the colonies): in Africa, those troops were assigned to serve in the garrison of the AOF (Afrique Occidentale Française - French Western Africa), AEF (Afrique Equatoriale Française - Equatorial French Africa), ${ }^{3}$ Madagascar (as well as in Indochina and New Caledonia);

- The indigenous troops were recruited to any one of the above. These indigenous troops were serving as part of the French army: they were put under the supervision of French officers and were designated as Tirailleurs (skirmishers). There were Tirailleurs in each of the African Francophone countries (Tirailleurs sénégalais, malgache, etc.) but the generic designation 'Tirailleurs sénégalais' was the name given to all West and Central African regiments.

Whether French or indigenous, these troops were mostly long service regulars. Contrary to the armed forces of the Anglophone colonies, ${ }^{4}$ the French colonial troops recruited soldiers in all African territories under French rule, and used them in any place, without taking into account their geographical origin.

In the territories of AOF and AEF, the maintenance of law and order was a responsibility shared by all the colonial troops. There were two noticeable exceptions however, with two specialised bodies that were part of the colonial troops but specifically entrusted with police and law enforcement missions.

4 Most of the African regiments who served in the British colonial army mainly included soldiers who originated from the territory in which they were assigned. 
First, the colonial gendarmes. Colonial gendarmes are almost exclusively established in Senegal. In 1904, the colonial gendarmerie officially began to recruit a body of African auxiliaries. The appearance of native auxiliaries of the gendarmerie took place under the following conditions: certain indigenous units were flanked by the French gendarmes and their police powers were almost non-existent. Officially, the native auxiliary was a scout and an interpreter. In Cameroon and in Congo only, the police were supported directly by native forces. Cameroon was one of the rare territories of Africa endowed with a gendarmerie, created in 1920. After WWI, the colonial gendarmerie was first in line in the coercive interventions against independence movements. In some countries, the gendarmerie is a heritage from both traditional forces and colonial gendarmerie: for instance, in Senegal, the history of the gendarmerie is closely linked to the story of the so-called 'Red Guard' ( $\mathrm{La}$ Garde Rouge), which was made up of the Saphis horsemen.

On the territory that would become Mali, Mauritania and Niger, camel troops (troupes méharistes) were created in 1894, by the Governor of Senegal under the name of 'Garde cercle' and then 'Garde goume'.

Some countries, such as Togo, still base their policies on doctrines that were imported during the colonial period which incorporates military and psychological control of the population, and aims to fight internal subversion.

After independence, the Tirailleurs were discharged and joined their new national armies, or police forces. It is important to note that during the first years after the independences, most of the new nations did not have an army. Apart from Guinea, all the newly independent states adopted the status of member-state of the Franco-African Community - which replaced the French Union in 1958 - and delegated to the Community their competencies in foreign policy and national defence. Consequently, former Tirailleurs were part of the armed forces of the Community and were not responsible to national governments. Initially, there were no Francophone African national armies (Lavroff 1976). The independent Francophone African states asked rapidly for the modification of their status for them to enjoy complete sovereignty. The armed forces of the Community were then disbanded, and France made available soldiers who had been posted in other territories, to the states that they originated from.

Consequently, from 1962 onwards, contingents from the Franco-African Community formed the first nucleus of the Francophone African armies. However, this movement did not result in the same kind of military apparatus in every country. Indeed, the colonial troops, and then the Armed forces of the Community, did principally recruit from some territories, particularly from those whose populations were considered 'good warriors'. Most Francophone soldiers were recruited in Senegal, Mali, Haute-Volta (former name of Burkina Faso), Togo and Niger, which consequently inherited bigger contingents than other countries. Some countries (Mali, Haute-Volta, Togo) were not able (for financial reasons), or willing (for political reasons, some soldiers being seen as too close to the former colonial power), ${ }^{5}$ to integrate all their national soldiers into their new armed forces, whilst

5 The coup attempted in Togo in 1963 by some non-commissioned officers is a good example of this situation: these soldiers did not accept that they were to be excluded from the national Togolese armed forces. 
some countries, where only a few soldiers had been recruited by France, had to recruit new inexperienced soldiers.

It is worth noting that following the adoption of the Law Deferre in 1956, the function of policing and law enforcement had been entrusted to indigenous forces placed under the supervision of local authorities rather than under French supervision. It was then decided that the colonial territories would have their own municipal and local police forces, the French general government being only entrusted with supervising the armed forces and ensuring the territorial defence of the territories. The objective was to unburden Metropolitan France of all the operations of 'maintenance of law and order', especially against trade unions and demonstrations by educated youth. ${ }^{6}$ The legitimacy of the power of the new autonomous authorities was in fact based on the establishment of national police forces to control African protesters fighting for independence. The devolvement of local police forces in the territorial authorities was primarily meant to ensure social and political pacification. In this respect, there is little doubt that the continuance of the colonial authoritarian tradition is closely tied to the insoluble social and economic problems which the new authorities had to face, and this played a major role in the fast militarisation of policing and law enforcement in the quasi-totality of the independent states.

\subsection{The 'special relationship' between France and Africa after independence}

From independence, France has been more deeply engaged in Africa than any other Western country (though the USSR, Eastern Europe and Cuba were also deeply engaged in states 'of socialist orientation' during the Cold War period). Any analysis of the security apparatus in Francophone Africa must bear in mind that relationships with France are critical to the understanding of the state of the security sector in a number of Francophone African countries. From the time of independence, a special relationship has prevailed between the new states and their former colonial powers (N'Diaye 2007). France kept close and constraining strategic ties with its former colonies: Paris was tied to them by a system of diplomatic, economic, cultural, and defence agreements. This special relationship between France and its former colonies is often referred to as 'Francafrique' in the Francophone literature, this pejorative word pointing out the shadow and nepotistic practices which used to characterise the relations between French officials and the post-colonial non-democratic leaders (Wauthier 1995; Smith 1996; Verschave 1998; Petiteville 1996; Charbonneau 2008).

In the realm of security, French intervention has consisted in ensuring its own access to base facilities; leading direct 'stabilising' interventions; and positioning military and security personnel and advisers in ministries. The essential characteristics of the Franco-African security relationship includes defence agreements (guaranteeing the continual presence of French troops in a number of Francophone states - Senegal, Djibouti, Gabon, Côte d'Ivoire ${ }^{7}-$ or mutual $^{2}$ 
defence clauses), military advisors and close military and police cooperation (including the training of officers and the sale of weapons and related equipment). From the 1960s, Francophone states have suffered the permanent presence of French troops, when linked to France by a defence agreement and therefore have been protected from external and in some cases internal aggression, with France serving as the guarantor of their sovereignty. Consequently, they have not developed strong military apparatus. In addition, the so-called 'coopérants' technical advisors (in the defence as well as in the police and justice sector) permanently deployed in Francophone African countries (for a two to three year period) have been deeply involved in assisting the newly independent authorities in putting on its feet a national security apparatus.

It is very important to stress the fact that the presence of permanently stationed French troops and the assistance provided by the French 'coopérants' on a daily basis has not prevented the Francophone African states from falling into statepersonalisation processes - where political rulers have politicised, manipulated or undermined the defence and security forces, notably by setting up parallel but more powerful forces. On the contrary, it can be argued that the effect of French cooperation as regards security is weak both in terms of governance and professionalism. It is doubtful whether French military cooperation really has enhanced overall security in Francophone Africa: the territory of France's Francophone allies has not been protected in a number of cases (Côte d'Ivoire, Guinea, the DRC); national or regional conflicts have not been prevented; the local population most of the time consider the military and the police forces as threats rather than as protectors; and those forces are rarely able to fulfil their missions (protection of the territory as regards the military, protection of law and order as regards the police forces), due to a lack of professionalism and equipment. On the contrary, French security policy can be seen as having contributed to strengthen bad governance in Francophone Africa, security technical support having mainly been provided to non-democratic regimes.

A lot should be learnt from the failure of French security cooperation in building up and reforming African security apparatuses since the independences. ${ }^{8}$

$8 \quad$ Whilst most of the specialists of the French African security policy (Barillot 1993; Ango Ela 1996; Balmond 1998; Chaigneau 1984; Dumoulin 1997; Gounin 2009; Luckham 1982; Gregory 2000; Smith 1996; Charbonneau 2008; Vasset 1997) have systematically and thoroughly analysed the political processes underlying Franco-African military relationships, one can hardly find a systematic and detailed assessment of the achievements of more than 40 years of French security cooperation with Francophone African countries: no detailed lessons learned have been completed, except (to some extent) in the 1996 and 2002 reports of the Observatoire permanent de la coopération française (1996, 2002). 


\section{General overview of the security apparatus in Francophone African states}

Despite having been independent for over 40 years, most of the Francophone African states have maintained many of the defence and security institutions imposed by France under colonial rule. A large number of former French colonies have inherited, from the legacy of the French, a three-tiered security apparatus. According to existing regulations under this system, national security is meant to be maintained by the army for external threats, and by both the gendarmerie and the police for internal security matters.

\subsection{Constitutional frameworks in the former French Colonies}

Francophone countries achieved independence between 1958 and 1960. All former French colony states experienced a single regime party immediately after independence while a majority of them were then put under a military regime (Lavroff 1984; Martin 1976; Pabanel 1984). The separation of powers was nonexistent, and the legislative and judiciary powers were highly dependent on the executive branch which, de facto, enjoyed all rights in terms of security.

Following the Conference de la Baule in 1990, which aimed to launch a democratic transition on the continent, most of the Constitutions of the Francophone African states were reviewed (du Bois de Gaudusson et al. 1997; Cabanis and Martin 1998a; Roussillion 1995; Daloz and Quentin 1997; Clark and Gardinar 1996) and went back to Constitutional principles inspired by the 1958 French Constitution, which established the Fifth Republic. The set of Constitutions (Cabanis and Martin 1998b) adopted during the 1990s espoused the principles of separation of power, and attributed specific competences to each branch within the management of the security forces (du Bois de Gaudusson et al. 1997): most of these Constitutions set out the principles that govern the organisation, use of, and supervision of the armed forces.

Below are presented the provisions that relate to security as envisioned by the 1990's Francophone African Constitutions. We will then focus on the kind of regimes that have currently been established in Francophone Africa.

\subsection{Constitutional provisions relating to security in the former French African colonies}

A constant feature of the institutional framework in Francophone African countries is that the President of the Republic presides over all the security apparatus, whilst the government - mostly through the Ministries of Defence, Interior/Internal security and Justice - is responsible for implementing security policies. In theory, there are several bodies which are responsible for coordinating the different components of the security apparatus. However, in practice, the Presidency has often kept most of the prerogatives, with some regimes developing abusive 
behaviours. This therefore demonstrates that the 1958 French Fundamental Law can pave the way to an authoritarian institutional interpretation as well as to a democratic institutional interpretation.

\subsubsection{Power sharing between the President and the government}

Most African Francophone states are semi-presidential regimes. According to the terms of most Constitutions in Francophone Africa, the executive power is responsible for taking the necessary measures to guarantee the security and the integrity of the national territories as well as to protect the population.

Following the French Constitution, Constitutions in Francophone Africa state that the President of the Republic is the Commander in Chief of the armed forces, whilst the prime minister is in charge of implementing the military defence policy. The President chairs all the 'organic councils on national defence' (article 15). He guarantees national independence, and the integrity of the territory (article 5, alinea 2). He appoints 'civil and military employments' (article 13). Meanwhile, the government 'disposes of the administration and the armed forces' (article 20). These provisions ensure the supremacy of the President.

Most of the Francophone African Constitutions appoint the President as the 'supreme commander in chief of the armed forces'. ${ }^{9}$ The President also has the power to appoint civilian and military positions (for instance the Chief of Staff of the armed forces, as well as other heads of the civilian and military administration). Appointments to the general staff, and to other bodies of the military and security units, are made at the council of Ministers. The President can also hold 'exceptional powers' and has the power to declare a state of emergency, though this can only be after consultation with his Council of Ministers.

With regards to the government, there is less unity among the Francophone Constitutions than with regards to the powers of the President of the Republic. The French assertion stating that the 'government disposes of the administration

9 The adjective 'supreme' was taken directly from the American Constitution: Burkina Faso (article 52 of the 1991 Constitution, amended in 1997); RCA (article 22 of the 2003 Constitution); Congo (article 78 of the 2002 Constitution); Djibouti (article 32 of the 1992 Constitution); Gabon (article 22 of the 1991 Constitution); Madagascar (article 55 of the 1992 Constitution); Mali (article 44 of the 1992 Constitution); Mauritania (article 34 of 1991, amended in 2006); Chad (article 86 of the 1996 Constitution, amended in 2005). Apart from Djibouti, this entitlement comes with the right to chair 'the high councils and committees on national defence'. However, there are six Constitutions that adopt a different formulation: in Cameroon (article 8 of the 1972 Constitution amended in 1996 and 2008), Guinea (article 41 of the 1990 Loi Fondamentale), Togo (article 72 of the 1992 Constitution amended in 2002), Niger (article 52), Senegal (article 39); Congo (article 78 of the 2002 Constitution), Presidents are simply appointed (as in the French Constitution) as 'chief of the armed forces'. In Benin (article 54 of the 1990 Constitution), the President is responsible for 'the external security of the Republic' (Benin is a noticeable exception in Francophone Africa: its regime is definitely presidential, unlike other Francophone states which have adopted a semi-presidential regime. In Benin, the Constitution does not mention a prime minister, while the government is supposed to be directly controlled by the President). 
and the armed forces' is often taken up by African Constitutions, but with some variations. ${ }^{10}$

In summation, according to the Constitutions, the President of the Republic, Supreme Chief of the armed forces, is able to define the national defence policy, which is executed by the Minister of the Armed forces, under the aegis of the prime minister. In practice, the security domain is, to a large extent, the exclusive monopoly of the President, assisted by a limited circle of civilian and military advisers.

\subsubsection{Legislative mandate: parliamentarian supervision and oversight of the security services}

Since the 1990s, the African Francophone Constitutions have established a system of separation and collaboration between the executive, the legislative and the judiciary branches (National Democratic Institute 1999; 1997). According to the French Constitution, the Parliament is in charge of declaring war and of ratifying peace agreements. Most Francophone African Constitutions also acknowledge that the Parliament has the responsibility to declare war. ${ }^{11}$

Moreover, as in France, most of the Constitutions of Francophone African states recognise that 'the fundamental principles of the general organisation of the national defence' arise out of the domain of the law. Thus, apart from in Togo (where there is no definition of the legislative sphere of responsibilities), all the Constitutions stipulate that their defence policies are passed into law by the legislature, though only after review by the appropriate committee.

The Parliament ${ }^{12}$ may call on the security forces to defend national territory, or to approve or amend any act relating to new alliances. Most of the time, it has to approve any engagement of its armed forces abroad. In Benin and Niger, the Parliament is entitled to adopt bills that ratify any international alliance: this includes military assistance agreements.

In most of the countries, the Parliament has the power to monitor the actions of the government through:

- consideration of the budget (including a faculty to approve the funds that are to be allocated to various security structures, to revise it downward or upward or to redirect budget allocations towards other areas);

10 Whilst Mali (article 53), Madagascar (article 3) and Mauritania (article 43-3) duplicate the terms in a similar way, there are three other Constitutions that extend these government's rights to the security forces: Burkina (article 61-3), Gabon (article 28-2) and Togo (article 77-1). Some Constitutions do not mention this responsibility (Djibouti, Guinea, RCA). Other Constitutions only entrust the government with the 'administration of the public force' as in Congo (article 89-1), or with the 'administration of the police forces' as in Chad (article 97-2 and 98-2). In Cameroon, the government is only entrusted with the disposal of the administration. In Benin, only the President can dispose of the armed forces.

11 Benin (article 101-1); Burkina (article 106-2); Djibouti (article 62-1); Gabon, with a two thirds majority (article 49); Guinea (article 75); Madagascar (article 82); Mali (article 81); Mauritania (article 58); Chad (article 127); Togo (article 72). However, the Beninese Constitution states that the President himself can declare war under 'exceptional circumstances' when the Parliament is unable to sit (article 101-2).

12 A number of Francophone African states have a bicameral parliamentary system. However, some countries have not yet set up their Senate (Cameroon). 
- questions to the government;

- Parliamentary standing committees.

There are standing committees on national defence, security and civil protection, specifically in charge of the security sector as well as standing committees on laws and justice. Like all other standing committees, these committees have a duty to monitor the actions of the government; they may hold audiences with Ministers, and call before them anyone who needs to be consulted. The committees receive draft bills from the government but, in some countries such as Benin and Mali, they may also propose laws on security issues. These committees are, however, mainly in charge of carrying out surveys and drafting amendments. They are not investigative bodies, nor are they units that provide direct control of the activities of the security sector, even if they are allowed to call on external expertise.

However, in a number of Francophone African states, there is virtually no parliamentarian control of the security forces. Despite the formal existence of parliamentary commissions on security and defence, the Parliaments have more than often been unable to oversee the security forces.

\subsubsection{Specific provisions against praetorianism ${ }^{13}$}

Most of the Constitutions adopted in Francophone African countries during the 1990 s and the 2000s have adopted provisions that aim to prevent the resurgence of military coups and praetorianism, which used to characterise most of the regimes during the post-independence period. In Francophone Africa, only Senegal, Gabon and Cameroon (and to a lesser extent Djibouti) have never experienced military rule. Consequently, the Constitutions seek to give the civilians the means to deter and defeat any military attempts at seizing power.

Such a preoccupation is present in most Constitutional preambles. Almost all the Constitutions affirm the principles of the democratic rule of law. For instance, the Togolese and the Beninese Constitutions exclaim in their preambles the 'strong will to fight any political regime based on dictatorship and injustice'. Some Constitutions, such as the Malian and the Chadian ones, remind us of the recent and sad political and Constitutional history. In its preamble, the Congolese Constitution clearly denounces the coups d'etat which used to be the only means of seizing power, and have inhibited the ability to have any democratic political life: the preamble calls upon all citizens to resort to civil disobedience in order to resist any attempts at seizing power by force, or attempts to exercise dictatorial rule.

Moreover, beyond these principles enlightened by the preambles, a number of provisions appear in the corpus of the Constitution. For instance, the Beninese Constitution dedicates one article (within the chapter dedicated to executive power) which calls upon any Beninese to disobey orders and organise resistance in the case of a coup d'état or seizure of power by mercenaries (article 66); this also allows external police or armed forces (article 67) to be called upon, especially within the framework of military cooperation or of defence agreements. 
The Burkina Faso Constitution also mentions that civil disobedience against any power is not constitutionally legitimate (article 167); whilst the Malian Constitution approves of disobedience in order to preserve a republican form of state. In Congo, the citizens are acknowledged to have the right not to execute an order which is seen to be against civil rights and liberties.

Some Constitutions (article 65 of the Beninese Constitution) consider any attempt against constitutional order as a 'high treason crime' (crime de haute trahison) or, as a 'crime against the nation' (article 166 of the Burkina Faso Constitution). To some countries, this kind of crime is not subject to prescription, as stated by the Malian Constitution (article 121-3), the Togolese Constitution (articles 148 and 149-4) and the Congolese Constitution (article 49).

Some Constitutions insist on the importance of civilian control. The Congolese Constitution indicates that the public force, made up of the gendarmerie, the police, and the military, is subordinated to civilian power (article 162-2). According to the Togolese Constitution, the armed forces are 'entirely subject to constitutionally established political authorities' (article 147). In Chad, security and armed forces are called upon to serve the nation (article 190-2) and are said to be subject to republican authorities and subordinated to civilian power. Beyond this, the Chadian Constitution explores in more detail the obligations of the police, the gendarmerie, the national and the nomadic guard to act respectfully in accordance with human rights freedoms (articles 197, 199, 201). However, the armed forces have not made the same obligations even if Chad (article 191-1) (as well as the Congo (article 162) and Togo (article 147)), do proclaim that the military have to be apolitical. The Constitution of Madagascar similarly calls for 'the political neutrality of the armed forces'.

In most of the Francophone African countries, the military are not prevented from aspiring to have an elective mandate, apart from Benin where the military who are currently in active service have to resign from their duties prior to making a presidential or legislative candidacy (according to articles 64 and 81), Djibouti where the military who are active are not allowed to present themselves as a candidate to parliamentary elections (according to article 47-6) and Togo (which has the same provisions as Djibouti, following article 52).

It is important however to stress the fact that such constitutional principles have proved to be particularly inefficient: the current resurgence of military coups and praetorianism in Francophone Africa urges us to raise this key question: 'What is the value of Constitutional laws when faced with 'bayonets'?

\subsubsection{Conscription and military service}

It is hard to find provisions that deal with the French traditional model of conscription in the Constitutions of Francophone African states. A number of these Constitutions deal with 'the defence of the country and the territorial integrity as a duty for all the citizens', as stated by the Beninese (article 32), the Chadian (article 51), the Nigerian and the Togolese (article 43) Constitutions: in these countries it is said that military service is obligatory. Other countries only ask their citizens to contribute towards the defence of the nation, as stressed by the Burkinabe (article 10-1), the Centrafrican (article 16), the Gabonese (article 1-21) 
and the Malian (article 22) Constitutions. In Mali, only nationals who are recruited to serve in public service are obliged to do compulsory military service.

\subsubsection{The model of a developmental army}

Traditionally, most Francophone countries have a role envisioned for their armies in both economic development and in education.

In a number of countries, the Constitution states that the armed forces may participate in the economic, social and cultural development of the country. Some Constitutions plead for enlarging the missions of the armed forces by involving them in the social and economic development of the nation, as stated by the Congolese (article 168), the Gabonese (article 1-22) and the Chadian (article 194) Constitutions. The Congo even considers that their armed forces can take part in the cultural development of the nation, while Chad assigns humanitarian missions to them.

Even if these missions are not explicitly mentioned in the Constitutions themselves, missions that more generally involve the military in development or humanitarian projects are often considered as a possible role for the armed forces. Because of its resources, the military is often seen as the only organisation most able to perform a wide range of developmental tasks in more remote areas. The use of the armed forces is seen as a way of creating a combination of interests between the population and the military.

For a lot of the time, the Engineering corps in every Francophone country is involved in development/humanitarian missions as well as the Health Service. The armies of Mali and Benin have been particularly active in this area (training the public in basic hygiene and sanitation; implementing inoculation and vaccination campaigns; building or repair of schools and/or roads; as well as providing air transport facilities to remote areas).

\subsubsection{Administrative and territorial organisation in the former French African colonies}

With regards to the security apparatus, the administrative and territorial organisation of a state does matter. Indeed, some security institutions (for instance the municipal police, where they actually exist, or the military regions that are generally based at the territorial division of a country) are supposed to work closely with decentralised entities (e.g. mayors). A growing number of SSR programmes envision the making of decentralised authorities which will be given more responsibilities within a security area.

Most Francophone states have inherited the French system of a highly centralised state. Before the wave of decentralisation in the 1990s, the territorial division of Francophone countries was composed of departments, districts (arrondissements), administrative posts and communes which were originally merely administrative bodies. These structures were therefore only devolved, since they were administered by representatives appointed by the state. Nowadays, most of the Francophone states formally recognise both administrative zones and local authorities. Inspired by the French decentralisation process (launched in the 
1980s), most of the African Constitutions now recognise the right of local authorities to administer themselves freely. Territorial administration is contained within the Constitution, and local authorities are created by law. Consequently, a number of laws that deal with the decentralisation process were adopted in most Francophone African states at the beginning of the 1990s (mostly between 1993 and 1995); these have created local authorities in the provinces and in communes. These kinds of provisions generally result from an obligation to abide by the programmes of structural and institutional adjustment and an urge to implement regional development policies and administrative reforms, as well as an attempt to bring the state closer to those it administers and to favour local democracy.

The Francophone African territories are generally divided into:

- regions or provinces;

- departments: ${ }^{14}$

- communes (including those with a particular status);

- rural communities or rural circles in some countries;

- districts (Arrondissements) in big cities;

- quarters and villages.

According to existing laws, most of the regions, departments, and communes have their own fields of competence and their own financial resources.

As in France, communes are meant to be administered by mayors appointed by municipal councils and elected by direct elections. Territorial bodies are supposedly free to run their own affairs, under the supervision of a state representative. The state is present locally through a system of administrative authorities: prefects, subprefects and, in some cases, administrative posts. In most countries, the region is both an administrative sub-division of the state and of a local authority.

However, in a number of countries these provisions are far from effective: in urban and rural communes and in the provinces, communal elections, while planned by the Constitution or by the law, have never actually been held. At each administrative level, the authorities are appointed by the central authorities, including when they are supposed to be elected.

\subsection{Democratic versus authoritarian regimes}

As mentioned above, most of the Francophone countries formally embraced democratic political reforms in the early 1990s. The first set of multiparty elections was held between 1991 and 1993. However, achievements in democratisation of the security apparatus vary from country to country. It is necessary to make a distinction between the security apparatuses which are operating within this institutional framework in a democratic way and those which are using it to foster their dictatorial rule.

14 Some countries, such as Guinea, have neither departments nor regions; or they only exist in theory as in the CAR. 
Countries such as Senegal, Mali, and Benin can be considered as having a security apparatus operating under democratic rule. In the two latter countries the military played a central role in enforcing democracy. By maintaining its neutrality through the democratic transition and during the first two presidential elections, the Beninese military contributed to the conduct of transparent elections. In Mali, after the coup led by Amadou Toumani Toure to overthrow the military ruler Moussa Traore, the military remained true to its avowed goal of democratic restoration and allowed a peaceful transfer of power to the newly elected President Alpha Oumar Konaré in 1992. From 2005 to 2008, Mauritania seemed to be on the same kind of trajectory: the coup led by Colonel Ely Ould Mohamed Vall, which ended Maaouya Ould Sid'Ahmed Taya's twenty-one years of strongarm rule, had been generally accepted, while the military junta had organised elections. The leader of the junta, Col. Vall promised to relinquish power peacefully. The first fully democratic Presidential election since 1960, held on 11 March 2007, had been initially seen as the final phase in the transfer from military to civilian rule following the military coup in 2005. However, on 6 August 2008, the head of the Presidential Guards - General Mohamed Ould Abdel Aziz, former Chief of Staff of the Mauritanian army - overthrew the democraticallyelected government.

In contrast, in Togo, Guinea, Congo, Chad and to a lesser extent Gabon, the Central African Republic or Cameroon, personal powers respect no constitutional limitations, even when these exist. Many institutions of democratic control of the security sector (for instance Ombudsmans and Mediators, Public Account, Human Rights Commissions) have been created but do not function. From an institutional point of view, it is possible to make a distinction between undemocratic regimes headed by military leaders (Chad, the Central African Republic, Guinea, ${ }^{15}$ Congo-Brazzaville, Burkina Faso) and undemocratic regimes operating under civilian rule (Gabon, Cameroon, Côte d'Ivoire, Togo): ${ }^{16}$ however, this institutional difference does not have any particular implication as regards the security apparatus. In the two sets of countries, the security sector is mainly characterised by bad governance.

\subsection{Institutional organisation of the security apparatus}

In France, the fundamental principles of the national defence and security organisation refer to the domain of legislation. In most of the Francophone African countries, the organisation of the security apparatus is also fixed by laws.

\subsubsection{National security organisations}

Most Francophone states do not have National Security Councils. In a number of countries it is the Constitution that sets up High Councils on National Defence.

15 Despite the control over the army, the Guinean army experienced regular mutinies, organised by soldiers advocating for higher pay, better working conditions and demands for compensation from the families of Guinean soldiers killed while on peace missions. These mutinies were severely repressed, except the last, in April 2008, Lansana Conté having agreed to negotiate with the leaders.

16 Since the death of General Eyadéma in 2005, his son Faure Gnassingbé has become Head of the Togolese state. Faure Gnassingbé is a civilian but is supported by the military. 
Besides the Constitutional provisions, it is hard to find information relating to these organisations because most of the time, these structures are just hollow and empty shells, as in Cameroon and CAR.

In Guinea, a Supreme Council on National Defence, presided over by the President, was set up, but it is hard to find information about its membership, functions and objectives.

In Mali, there are two main bodies that are in charge of the general security sector and these are under the direct authority of the President of the Republic:

- The Higher Council on National Defence: located in the Council of Ministers, it is the decision-making and advisory body on issues related to general defence. This Council is made up of representatives from military personnel and representatives from the military command structure. It is chaired by the President of the Republic and includes the prime minister as well as the Ministers of Defence, local Government and Decentralisation and Ministers of Finance and Foreign affairs. A similar organisation can be found in Burkina as well;

- The National Defence Committee which is chaired by the President of the Republic. It includes the prime minister, the Minister of Defence, the Chief of Staff for national defence, the armed forces Inspector General and the Chiefs of Staff of the Defence services.

The administrative function of these two bodies is carried out by the General Secretary for National Defence (part of the Prime Minister's Office, which is similar to the SGDN - Secrétariat général de la Défense Nationale - in France).

Moreover, the Council of Ministers, under the authority of the prime minister, is a second level of coordination. Finally, in theory, a single ministry can contribute to the coordination of the security apparatus when it is in charge of the activities carried out by several services. For instance, in Mali, the Minister of Internal Security is in charge of the police, the gendarmerie and the National Guard.

In some countries, such as Burkina Faso, a coordinating unit for internal security forces was implemented in 2001. This unit, under the direct responsibility of the Minister in charge of Security, includes the permanent secretary of the Ministry of Security, the Chief of Staff of the National gendarmerie, the Chief of Staff of the national police force and the Chief of Staff of the national fire brigade. It is in charge of coordinating, designing and monitoring national security policy and is responsible for organising and coordinating the activities of law enforcement forces, both in their administrative and investigative missions. The unit also oversees the activities of the armed forces when they are asked to protect institutions, persons or goods. It also programmes the procurement of materials and equipment used by security forces. In Burkina Faso, there is also a Ministerial Committee on Defence Intelligence which is chaired by the prime minister.

\subsubsection{The Minister of Defence}

The defence policy is implemented by the Ministry of Defence. The Minister of Defence/Armed forces is generally in charge of the implementation of military defence policy under the authority of the President. He is responsible for 
organising the armed forces and responsible for ensuring that they are operational by providing them with the resources, equipment and infrastructures that they require. He also has the responsibility for military cooperation with foreign countries.

However, in a number of countries, the Presidents of the Republic violate the provisions of the Constitutions and cumulate their function with the function of the Ministry of Defence. In Cameroon, Paul Biya is de facto the Minister of Defence: there is only a Deputy Minister of Defence and a National Security Delegate for internal security there. In Guinea, President Lansana Conté has retained the portfolio of the Ministry of Defence for several years. In the Central African Republic, the President also holds the portfolio of the Ministry of Defence. Furthermore, in a number of countries (e.g. Togo), Ministers of Defence - as well as Ministers of the Interior - have been appointed from the military. ${ }^{17}$

\subsubsection{The armed forces in the former French colonies}

During the post-independence period, the national armed forces were the central institution of the security system in a number of Francophone states: they were thought of as the cornerstone of the security system. Rather than coping with external threats (often thanks to the protection guaranteed by the defence agreements with France) the national armed forces turned out to be a political instrument of the regime in power and mainly fought the political opposition.

It is often far from easy to assess the number of people who are directly employed in the defence sector in Francophone Africa accurately.

\subsubsection{The Chief of Staff}

The Minister of Defence is assisted by the Chief of Staff, who also generally serves as the military advisor to the government. The Chief of Staff ensures the general command of the armed forces, with the assistance of various force commanders and the directors of joint force units (in some countries such as Benin, a Military High Command coordinate them). The General Staff is placed under the direct authority of the Minister of Defence and serves as the central command and coordination unit of the armed forces.

In some countries such as Niger, the single structure of the armed forces - with a unique military chain of command placed under the authority of the Minister of Defence and under the responsibility of the Chief of Staff - has been abandoned. From now on, two separate branches - the army and the air force - have been set up and each is placed under the command of its own Chief of Staff.

17 Some regional prefects, directors of state companies, and directors of customs services are also appointed from the military. 


\subsubsection{The armed forces' services}

In the sections below, there will be a focus on the defining characteristics of the Francophone armed forces. ${ }^{18}$ It is important to note that all the developments relating to the corruption of the armed forces (as well as the police forces) in Anglophone Africa (cf. below) are also valid with regards to Francophone Africa.

\subsection{The militarisation of internal order}

In democratic Francophone African states, the armed forces are only involved in external defence missions (protection of the sovereignty and territorial integrity of the state), except in cases of exceptional circumstances (e.g. a state of emergency or natural disasters). They can also sometimes be involved in socalled 'development missions'. In an autocratic country such as Cameroon, the armed forces are also limited to carrying out defence missions (except when they are fighting against the so-called 'coupeurs de route').

On the other hand, states such as Togo, Guinea and Chad base dictatorial rule upon their armed forces. The armed forces are released from their conventional duties e.g. territorial defence and serve as a tool of territorial and political control of the population. This tendency has resulted in the militarisation of policing.

The public's confidence in the security forces has been eroded by the repeated intervention of the military in domestic assignments of law enforcement. In Guinea for instance, army tanks were intermittently deployed in the streets during peace time, whilst in the Congo, the presidential guard was the first outfit to be deployed in the event of internal security problems.

\subsection{Ethnic forces}

The ethnicisation of Africa's military forces is an enduring feature of a number of Francophone African militia. Contrary to Anglophone Africa, this ethnicisation process cannot be analysed as the result of the Africanisation process of the armed forces. Indeed, as suggested in the introduction, French military advisors and coopérants have been very influential within the Francophone military since independence: the ethnicisation processes in a number of countries have been led without the complete withdrawal of the former colonial power.

The armed forces are highly ethnicised in Togo, Guinea and Chad, being largely dominated by the ethnic group of the President (The Kabye in Togo, the Mandé, the Soussou in Guinea and the Zaghawas in Chad). In CAR, even if President Bozizé is not currently leading any ethnicised policies, the policies of his predecessors (especially those of President Kolingba and of Patassé) have resulted in an ethnicised military, dominated by the Yakoma and, to a lesser extent, the Sara ethnic group.

18 The gendarmerie which is a military force that has been empowered to undertake police missions, and which has no counterpart in Anglophone Africa, will be dealt with in the section dedicated to police forces. 


\subsection{Professionalism and operational effectiveness}

All Francophone African armed forces are made up of a combination of an army, an air force and a gendarmerie. However, the armed forces are under-resourced in terms of staff and equipment. The existence of defence agreements with France and the presence of French forces stationed in some countries (Senegal, Côte d'Ivoire, Djibouti, Gabon, Chad and CAR until 1997) on a permanent basis, often deter Francophone African rulers from developing the readiness of their forces. The policy led by Félix-Houphouët Boigny in Côte d'Ivoire, until his death in 1993, is a good example of such a phenomenon.

Senegal can be seen as the only Francophone country with a professionalised, republican and well-trained army. The lack of professionalism can often be explained by the lack of transparent and merit-based policies. The criteria for recruitment and promotion within the armed forces is characterised by a high degree of opaqueness. This situation has created a climate of suspicion and frustration, which is not very favourable to the esprit de corps. Privileges and promotion are more often than not allocated on a subjective basis, and even in countries where there is no exclusive ethnic-based policy, ethnic affiliations and regional ties do matter more than professionalism.

Coastal countries, such as Senegal and Cameroon, have navies, but they are illequipped and seldom operational. In a lot of Francophone countries, the air force is more implicit than effective. In most cases, there are simply no aircraft, and the air force's personnel are employed in other services. In fact, the navy and the air force can be seen as token forces. Chad and Côte d'Ivoire are noticeable exceptions.

This lack of effectiveness of the armed forces may seem paradoxical considering that we have underlined the process of militarisation of internal order. In fact, only some of the armed forces units have been involved in internal law enforcement missions; for instance, the Presidential Guards.

\subsection{The Republican/Presidential Guards}

Officially, the mission of the presidential guard is to protect the Head of State when he travels abroad or within the country, and the presidential residences. The Presidential Guards are usually drawn from the rank of the military (officers and non-commissioned officers) and the gendarmerie. However, the Presidential Guards - called the Republican Guard in some Francophone African countries which makes reference to the French Republican Guard - are often configured as praetorian bodies: in Guinea they are, incidentally, called the 'Praetorian Guard'. These forces are usually appointed on the basis of their loyalty towards the President and recruited according to ethnic criteria. In a lot of Francophone countries, the Presidential Guard is the core security body in non-democratic countries such as the Central African Republic, Guinea ${ }^{19}$ and Mauritania (prior to and after the 2005 coup). These units are accountable to virtually no one except the President. Even if they are formally integrated into the armed forces' chain of command, these Presidential Guards are not accountable to the Chief of Staff or to the Ministry of Defence. 
Presidential Guards can be found in less authoritarian states: for instance, there is also a Presidential Guard in Cameroon, but its influence bears no comparison to those of the three countries mentioned above. Even if their missions are less outrageous, they enjoy special status. In Burkina Faso, the Presidential Guard is an autonomous security force, although it is technically subject to the jurisdiction of the armed forces and part of the army. In Niger, the former Republican Guard (the oldest existing corps of Niger's armed forces) were merged in 1997 with the members of the former rebel movements, and incorporated into the force following the peace agreements signed between 1995 and 1998. The new force is called the FNIS (National Intervention and Security Force), and is an autonomous corps, which comes under the responsibility of the Minister of Interior. The FNIS is responsible for maintaining order in some areas (mostly rural areas and the protection of public buildings in urban centres). They can also provide protection to the high official travelling in the rural part of the country.

In a number of countries (e.g. CAR, Niger), the Presidential Guards are also responsible for providing guard services in prison.

The Presidential Guards are one of the major symptoms of the system of competing security agencies and parallel chains of command which characterise the military in Francophone Africa. The Presidential/Republican Guards are generally better equipped than the other armed forces and they also enjoy virtual immunity for the crimes and abuses that they commit.

\subsection{The National Guards (Mali, Niger, Mauritania, Chad) ${ }^{20}$}

In Mali and Mauritania, the National Guard carries out important duties both military and civilian in essence. It contributes to maintaining order and public safety as well as to the general policing of territorial communities. It is entrusted with providing security to political and administrative institutions. It is also involved in the prison services. What is distinct about the National Guard is that it has the ability to grow into a formidable fighting force, capable of serving alongside the army. In Mauritania, the National Guard has served as a balance to the army. It was credited with saving Ould Taya's regime in 2003 during the coup attempt led by elements of the army.

The National Guard is managed by the Minister of Defence but in operations is put under the authority of the Minister of the Interior (sometimes called Minister in charge of (Internal) Security).

Generally, a Chief of Staff heads, coordinates and controls the activities and duties of the division commanders and the heads of units (who command the territorial units in the provinces).

The National Guard is present all over the national territory and works essentially for the benefit of the administration and the population. It is a highly decentralised force. The territorial organisation of the National Guard is duplicating the administration division of the country. National Guards are particularly worth considering because they have been recently reformed during the 1990s in order to integrate members of former rebels' movements from the Sahelian region. 


\subsubsection{Military justice}

There is still no military code of justice within some African Francophone countries. Elsewhere, the ordinances which govern the statute of the military in Francophone countries in Africa can hardly be found. In Congo-Brazzaville, the military court is made up of magistrates who are appointed by decree. In Niger, for instance, soldiers that commit crimes and offences are tried by civilian courts. However, in 2002 a tribunal was set up by the government that was in charge of dealing with mutinies. This regulation was based on the legislation of countries that had the same legal traditions (Senegal, Mali, Burkina Faso, Côte d'Ivoire).

\subsubsection{Legacy from the socialist regimes}

It is worth mentioning that, post-independence, a number of Constitutions were inspired by Marxism-Leninism - or Chinese communism - in Mali, Benin, Guinea, Congo-Brazzaville, the Central African Republic and Chad. Consequently, the security apparatus of these countries has some legacy from the cooperation with the Soviet Union (especially with regards to equipment and a culture of secrecy).

Under military leadership, Benin and Congo were formally known as the 'People's Republic', and adhered to Marxism-Leninism until the fall of communism in 1989.

In these states (NDI 1997) with socialist leanings, the army was often fully politicised. The situation in Guinea, the only Francophone state to have chosen independence in 1958 when France tried to reconfigure its colonial empire, is a good example. Guinea, which was under one-party military rule, adopted socialist policies and developed close political ties to Eastern Bloc countries and the People's Republic of China. Marxist ideology determined the structure and organisation of the military and heightened the role of the armed forces in society, thereby determining their relations with other sociopolitical organisations. Sékou Touré opted for a socialist approach to civil-military relations, which included the concept of 'militants in uniforms' as the cornerstone of Guinea's military status. The military was thus to be the armed branch of the single party, and replicated the party's organisational structure. For example, a military committee was set up in every political structure which competed with the regular military chain of command. An officer was specifically politically indoctrinated within each unit. The armed forces, as well as the civilian militarised units, were given the duty of defending the Guinean Revolution. The military was organised as an army of citizen soldiers that were fully integrated into society. This tradition continues to this day. In the Congo-Brazzaville, during the socialist era, the military, the gendarmerie and the police had combined command structures. This kind of tradition has often resulted in confusion amongst the civilian population who have difficulty in distinguishing the army from the police or the gendarmerie.

\subsubsection{Police forces in Francophone Africa}

One of the defining features of Francophone states relies in large part on the kind of security forces which are responsible for the maintenance of internal order. In most Francophone African countries, that used to be under French colonial rule, the policing system is modelled on the French system, and is centrally controlled. The police system in these countries is, therefore, French in its organisational structure, equipment and nomenclature. 
Two different services are nationally involved in the protection of internal order: ${ }^{21}$

- the police forces;

- the gendarmerie forces.

In addition, in some countries municipal police forces operate alongside these two forces and are under the mayor's supervision.

The paragraphs below focus on the way in which policing functions in Francophone Africa; however, it is important to note that the militarisation of the internal order mentioned above (paragraph 3.4.3.2.1) has resulted in a weakening of the police forces in most of the Francophone countries. More frequently, police forces are under-staffed and under-equipped and are therefore unable to cope with public insecurity. Under-paid, the police forces are often the most corrupt security bodies and the population consequently see them as a danger.

\subsubsection{Organisational, territorial and functional divisions between police forces}

To understand the way in which policing functions in Francophone African countries, it is necessary to make a threefold distinction:

- First, there is an organic division between the police forces and the gendarmerie forces. The gendarmerie is a paramilitary organisation, whilst the National Police are a civilian force. The National Police comes within the jurisdiction of the Minister of the Interior (Security/Internal security/and Decentralisation). The National Gendarmerie is part of the military forces, and comes under the jurisdiction of a General Directorate of the Ministry of Defence. However, in operational matters, the gendarmerie has to respond to the agency that requires and asks for its services;

- Second, there is a territorial division. Police units usually carry out their duties in urban areas and cities, whereas the gendarmerie intervenes in rural areas, and at borders (sometimes along with forest security and customs units);

- Third, there is a legal/functional division between the functions of the administrative police and the 'police judiciaire'22 (although this distinction is not always apparent, since police personnel can fulfil both functions).

\subsection{Administrative police and police judiciaire missions}

In addition to the rural/urban and paramilitary/civilian divisions between the gendarmeries and the police forces, there is a legal and functional division within

21 Internal order relates to the protection of public order against disruption, to the protection of institutions against insurrection, and to the enforcement of judiciary and administrative decisions.

22 In Francophone countries, the term 'police judiciaire' relates to the police services responsible for criminal investigations and prosecutions. In English, there is no relevant term to faithfully translate police judiciaire. The difficulties in translating the term cannot be seen as purely linguistic. On the contrary, they are a symptom of the conceptual differences existing between Francophone and Anglophone security systems, particularly as regards the policing system. Interestingly, it is also difficult to find a satisfying translation for the term 'gendarmerie'. That is why the author has chosen to use the French terms throughout this text. 
each of the two police forces, between the administrative and the investigative police (the police judiciaire). These two functions are exercised both by the national police and the gendarmerie. Therefore, members of the two police organisations have the status of both administrative police and police judiciaire:

- The administrative police are characterised as being, essentially, for preventive purposes, responsible for the protection of persons and property, and for law enforcement. Both the National Police and the National Gendarmerie are in charge of responsibilities such as maintaining order, controlling and preventing crime, enforcing public peace, looking after public health, and regulating traffic;

- The police judiciaire is responsible for the detection of crime, investigation of crime and the arrest of suspects. In some countries, in addition to the two police forces, some administrative authorities, such as the prefects, can also be considered as police judiciaire officers. ${ }^{23}$ The police judiciaire agents of the two police forces mentioned are specifically trained to be responsible for discovering crimes, for gathering evidence and to seek out offenders. In both organisations the police judiciaire are answerable to the Minister of Justice. When they act as police judiciaire, the police and the gendarmerie forces come under the authority of the courts, particularly the juge d'instruction (examining magistrate) and the procureur (prosecutor). ${ }^{24}$ The police can be officers of the courts along with the examining magistrates and prosecutors. Under the instructions by an examining magistrate, officers of the police judiciaire have the power to detain suspects for questioning for 48 hours or, if approved by a public prosecutor, up to 96 hours, in order to investigate an offence, to prepare the proceedings of the inquiry and to receive complaints and the charges and declarations of those who have an interest in the case.

The preventive/administrative police and the police judiciaire are closely tied and complementary to one another. When the administrative police fail in their mission of prevention, the police judiciaire are then activated. Yet both of these activities are carried out by the same personnel.

\subsubsection{The national police forces}

As with the gendarmerie, the national police force is in charge of gathering and processing intelligence, and of ensuring internal security and public order. Policemen are the first class of force who can maintain public order. The gendarmerie becomes involved as the second category force. Under exceptional circumstances (e.g. in a state of emergency), the armed forces may be called in as a third category force to back up the police and gendarmerie forces with law enforcement missions.

23 In some countries, such as Senegal, the prefects have lost their police judiciaire officer's status since the reform of judiciary procedure in 1985 .

24 Within their investigative responsibilities, the police judiciaire works under the supervision of the judiciary power: 'while they may opportunely collect evidence to establish that a crime has been committed, they must present said evidence to the court and, once legal proceedings commence, they are subject to the direction of the examining magistrate (juge d'instruction) and the prosecutor' (in Das and Palmiotto 2006). 


\subsection{Organisation}

Most of the time, the General Directorate of the National Police (Direction générale de la police nationale - DGPN) comes under the responsibility of the Minister in charge of security (for instance Mali, Benin), or under the responsibility of the Minister of the Interior (Niger). ${ }^{25}$ In a large number of Francophone African countries, the control of the National Police Force is still seen as a political matter with the Chief of Police, and his lieutenants, as nominees of the President of the Republic.

The Director General of police coordinates the activities of all the police departments. The General Directorate of the National Police manages both internal and external matters of the organisation and is assisted in this task by:

- The General Inspection of Police Services (Inspection générale des services de Police), which is a technical division that helps the General Director to carry out his role that relates to the general control of police personnel (with respect to the deontological rules, statutes and budget management). This service leads inspections and controls and evaluates the functioning of administrative, technical and operational services, as well as leading administrative and disciplinary inquests of police agencies and personnel;

- The General Secretariat of the Police Services (Secretariat général des services de Police), which is the technical division that helps the General Director to manage human resources, financial services and equipment. This service develops and maintains the police's real estate, centralises personnel needs, manages the police archives, manages schools, promotes social, sanitary and cultural operations within the police service, and pre-processes payroll operations and the liquidation of pension rights.

The Directorate General of the National Police is often divided into the following departments:

- The Department of Public Security, in charge of maintaining public order and controlling common offences (assaults, rape, theft, fraud, mugging...); it is often the largest component of the police force. Regional departments of public security are generally allocated to each administrative region, whereas police stations are located within cities;

- The Criminal Investigation Department (police judiciaire), which is the department that investigates and prosecutes major and organised crime. The criminal investigation department carries out investigative missions and assists with judiciary power: it is the department that is in charge of investigations and prosecutions ordered by the public prosecutor, or by the court, in cases of offences ${ }^{26}$ of common law.

- The territorial surveillance department, which issues permission to enter or exit the national territory (counterpart of the so-called police aux frontières in France).

25 In some countries, such as Burkina Faso, police services are headed by a Director of Security Services, with at least the rank of Chief Commissioner.

26 In Burkina Faso, the criminal investigation department is made up of members of the gendarmerie, the police force, and public administration, which is appointed by the government to this department. 
- The intelligence department is responsible for administrative inquiries and individual surveillance. In some countries (Côte d'Ivoire for instance), intelligence staff are allowed to carry hand-weapons. ${ }^{27}$

Each department is organised into several more general departments, regional departments, provincial departments, country desks and services. In the various regions, departments are placed under the administrative authority of the regional governor, and under the technical authority of the director general. This dual layer of hierarchical and technical authority enables regional governors to carry out their roles as both regional public services, and chiefs of security in their area of expertise.

In some countries (e.g. Benin), the police forces also encompass several rapid, specialised intervention groups, such as the crime squad, and the Compagnies Républicaines de Sécurité (CRS), inspired by the French counterparts, which are used to handle local emergencies and rescue operations. In emergencies, police prefects can call upon the Minister to request the use of any CRSs in his jurisdiction.

\subsection{Grades and functions}

The National Police are organised into four corps; there are a number of levels within each (Kurian 2006):

- Sergeants and constables. Within this group, the levels are: probationary constables, second-class and first-class constables, sergeants and staffsergeants in the sergeants and constable corps;

- Peace officers. There are three levels of staff officers;

- Police inspectors. There are five levels of police inspectors;

- Police commissioners. There are six levels of commissioners (probationary commissioner, second and first class commissioner, principal commissioner, divisional commissioner and controller general of the police).

Furthermore, there are two levels within the police judiciaire services: higher ranking officers of the Gendarmerie are commissioners, and officers of the National Police; lower ranking personnel are agents of the police judiciaire. It is they who gather information and intelligence, as required, and report their findings to their superiors.

In theory, recruits are selected by competition for direct entry into one of the four corps. To pass from one corps to another, a candidate has to pass a professional examination to make the necessary educational upgrade and to be promoted. They must hold citizenship of the country, and not be deemed to be ineligible by certain terms of the penal law, have completed their military service, and to have passed a background check. They then enter a police academy to receive the appropriate training for their corps. However, these provisions are often ignored,

27 In some countries, such as Côte d'Ivoire, there is also a commercial police department that is responsible for preventing and sanctioning economic offences. 
and a number of policemen (if not the majority of them in some countries) are recruited according to biased and often nepotistic criteria.

\subsubsection{The municipal police}

In some Francophone countries such as Burkina Faso and CAR, municipal police forces operate, along with national police forces based in towns. However, in a lot of countries, municipal police forces only exist in theory (Mali, Benin).

The municipal police are generally controlled by the Ministry of Territorial Administration. Supervising municipal police services is one of the responsibilities of the municipalities. Therefore, the municipal police come under the authority of a mayor and operate under a municipal police commandant. Its main functions are to assist mayors with applying police regulations, supporting other municipal services and providing ceremonial services. The municipal police are generally unarmed and have no investigative/criminal authority (Faupin 2005).

Coming under the Home Office and directly ruled by the authority of the mayor, the municipal police are charged with ensuring safety, security and public health. The municipal police are a police of proximity. Their attributions are to:

- ensure the safety and the convenience of public activities on streets, public highways and other public facilities - notably the cleaning, the lighting, the removal of congestion, the demolition or the repair of unsafe/contaminated buildings;

- repress infringements on public tranquility (fights, crowds, noise and nightgatherings);

- maintain order during large gatherings;

- inspect the accuracy of measures of foodstuff sold by weight or by measure and the healthiness of the edible food on sale;

- ensure the protection of persons and of public and private goods;

- guarantee the preservation of public places like waterways, forests, and hunting and fishing services.

The municipal policemen have an obligation to report all occurrences falling under the jurisdiction of the National Police which would have been missed and to give assistance in any place to repress breaches of the peace, and to maintain the morality and orderliness of the city. They submit reports in the following domains: hunting and fishing, traffic of drink, drugs and tobacco and opportunistic smuggling, food hygiene, public drunkenness, and coordination of local public transport, telecommunications and electricity supply.

\subsubsection{The gendarmerie}

The gendarmerie has no equivalent in Anglophone Africa. The gendarmerie is a specialised militarised force that is responsible for maintaining internal security and reinforcing the duties of the national police (Revue Frères d'arme 2009). 
The gendarmerie can be defined as a civilian police force with military status. Because of this military status, and with its status as an armed force, the gendarmerie falls under the control of the Defence Ministry in all Francophone countries. But the gendarmeries often have a double affiliation with the Ministry of Defence and the Ministry of the Interior: whilst the gendarmerie formally remains part of the armed forces, and the Ministry of Defence is in charge of its administration, the operational supervision lies with the Ministry of the Interior. The Ministry of Defence is responsible for budget, recruitment, education, training, equipment, administration and logistics of the gendarmerie forces. The gendarmerie can contribute to the defence of the country, when requested. However, the gendarmes are mainly responsible - in times of peace - for the protection of persons and property, the surveillance of territory and the maintenance of public order and law enforcement. In these times of peace, the gendarmerie is in charge of gathering intelligence in addition to providing internal security. That is why the gendarmerie are able to carry out their missions on behalf of other ministries, particularly the Ministry of Justice and/or the Ministry of Internal Security/the Interior. The gendarmerie is also in charge of the security of communication routes.

\subsection{Organisation}

The gendarmerie is organised militarily: its organisation is directly derived from the French model. In most Francophone African countries, the General Director of the National Gendarmerie (Directeur général de la gendarmerie nationale - DGGN) is directly responsible to the Minister of the Armed Forces and holds the same rank and advantages as the general Chief of Staff. In Senegal, the General Director is called the Gendarmerie High Commander. In Cameroon, gendarmerie forces are under the command of a Delegate Secretary of State, independent from the (Deputy) Minister of Defence.

In most Francophone African countries, the DGGN is for the most part a general officer, responsible for implementing the plans and directives that are decided by the Minister. It is important to mention that the DGGN is also in some cases the Director of the Military Justice.

Under the responsibility of the DGGN, the gendarmerie general staff is headed up by a general officer, appointed by decree, who is responsible for the organisation, coordination and control of the gendarmerie divisions. Most of the time, the general staff is divided between the following divisions:

- The Operations Division is in charge of the preparation of projects and directives that relate to the engagement and operations of the units (military operations, manoeuvres);

- The Information Division, intelligence service, is responsible for the collection, synthesis and dissemination of the information that is gathered on the ground by the units;

- The Staff Division is in charge of human resources management (recruitment, promotions, pensions, firing);

- The Military Justice Division is in charge of investigating the violations committed by the officers and soldiers, through its military police mission (prévôté). This 
division studies the cases, prepares the cases prior to sending them before the tribunals, and follows the legislation that deals with military justice;

- The Training Division is responsible for the training curricula. It designs pedagogic support resources;

- The Plan and Research Division;

- The Communication Division, responsible for public relations (internal and external) of the Gendarmerie.

The gendarmerie is made up of two sub-divisions, the so-called 'Major Commands' (Grands commandements): the territorial gendarmerie (gendarmerie territoriale) and the mobile gendarmerie (gendarmerie mobile). Each of these commands has its own general staff and administrative/financial services:

- The territorial gendarmerie is the cornerstone of the gendarmerie. The territorial gendarmerie is responsible for national territory surveillance, gathering intelligence, and the execution of investigative (police judiciaire), military and administrative police missions. To execute its missions, the command of the territorial gendarmerie is divided into:

- the legions. Each of these is made up of a number of companies, which are divided into several territorial brigades and one mobile squadron;

- a database, that is supposed to be closely connected to services that are in charge of national security (the intelligence services of the police forces - often called the RG and the DST as described below);

- a military police brigade, placed under the orders of the General Chief of the armed forces.

- The mobile gendarmerie is the second Great Command of the gendarmerie. The mobile gendarmerie is specifically responsible for law enforcement all over the national territory and for the protection of the authorities. It has absolutely no police judiciaire missions and its members are therefore not police judiciaire officers. It is often made up of two legions and the GIGN:

- The security Legion (légion de sécurité) is made up of three squadron groups that are located in the capital. These squadrons are in charge of the protection of public buildings (Presidential Residences, the National Assembly, Ministries, Courts of Justice) and with escorting official personalities;

- The intervention legion (légion de gendarmerie d'intervention) is made up of two squadron groups and one command squadron. They are specifically responsible for law enforcement and restoration and they have the capability of protecting national territory. It also participates in war operations alongside units of the army.

- The GIGN (Groupement d'intervention de la gendarmerie nationale). 


\subsection{Missions}

The missions and resources of the gendarmerie are generally fixed by a decree. The gendarmerie is essentially meant to ensure direct action by the administrative, judiciary and military police. The gendarmerie is also entitled to fulfil national defence missions, to assist the judiciary, administrative and military authorities, as well as assist all other ministerial departments. It therefore roughly fulfils four kinds of missions:

- police missions;

- national defence missions;

- public service missions;

- and, increasingly, a contribution to peacekeeping operations.

Police missions

With regards to its police missions, the gendarmerie is a force that is entitled to:

- $\quad$ rotect public safety;

- ensure law enforcement and the execution of the laws and regulations;

- guarantee permanent and preventive surveillance.

The gendarmerie carries out the function of criminal investigators in rural areas, under the authority of the relevant judiciary authority. In rural areas, the gendarmerie carries out the missions of the national police forces, for instance ensuring the safety of persons and goods, maintaining public order, as well as enforcing respect of laws and regulations. In rural areas, the gendarmes are mainly concerned with controlling crime, particularly illegal immigration, contraband trade across frontiers and black marketing. Most police services are delivered at brigade level. In most of the countries, the gendarmerie has regional headquarters in each region of that country, as well as brigades in the rural districts. Three types of policing missions need to be distinguished:

- The administrative police whose main purpose is to maintain order in a preventive way and which covers a broad range of missions: the general surveillance of persons and goods; traffic and road police; public sites police; civil protection and relief organisations; maritime police; air navigation police; economic police; fishing and hunting police;

- The police judiciaire. Their mission is exercised under the direction of the prosecutor of the Republic and under the control of the General Prosecutor. It

28 In some countries faced with an increasing criminality, the police functions of the gendarmerie, especially within the police judiciaire branch, have been increasingly reinforced. In Senegal, for instance, brigades specialising in criminal investigations have been created in each legion, and a new police judiciaire pole (pole de police judiciaire) has been created, with a new central database, and a new research section with investigators endowed with national authority. This research section is organised in different cells, which deal with all forms of delinquency (e.g. hold ups, money laundering, drug trafficking and drug consumption, youth delinquency). This empowerment of the gendarmerie occurred in association with the national police, and with the assistance of the French. 
assists with the recording of all crimes and offences against the law, in gathering pieces of evidence and in searching out the perpetrators - as long as judiciary information (information judiciaire) has been launched. The gendarmerie executes judiciary delegations and requisitions; ${ }^{28}$

- The military police. This mission aims to prevent disorder and to maintain discipline within military bodies, for instance by searching out defectors or keeping a watch on soldiers on leave. It assists with recording purely military disobedience as well as violations against civil law (droit commun) committed by the members of the armed forces. Gendarmes are thus responsible for controlling other military and paramilitary units, and for settling all disputes that involve soldiers and other military units.

\section{National defence missions}

With regards to its defence missions, the gendarmerie is generally organised around three core principles:

- Ensuring a general and permanent control of national territory;

- Ensuring the cohesion of the military defence areas (zone militaires de défence);

- Righting the administrative organisation of the national territory. In theory, there is one brigade in each sub-prefecture, one company in each department and one mobile squadron in each region.

Because it is deployed all over the national territory, the gendarmerie is a central player in the implementation of the concept of Operational Defence of the Territory (Défense opérationnelle du territoire - DOT):

- The gendarmerie protects the permanent secretariat of the regional defence committees, notably through the gathering of intelligence;

- In peacetime, the gendarmerie participates in exercises and military manoeuvres;

- In war time, the gendarmerie is called upon to fight alongside other military forces (not withstanding its military police mission).

- the gendarmerie also contributes to the general civil defence mission by providing intelligence information to specialised units, and by assisting any endangered persons.

- the gendarmerie is also a major actor in the field of civil protection.

Public service missions

The gendarmerie guarantees the safety of the great state institutions (the Presidency of the Republic, the National Assembly, the Courts of Justice, the Ministers) as well as the personal security of those in high authority (i.e. by acting as official escorts). It also provides assistance to any Minister or state administration in verifying the implementation of rules and laws or in searching out and disseminating intelligence information. 
When carrying out public service missions, the gendarmerie is placed under the supervision of both civilian and military authorities (Ministers of the Interior and Defence, as well as regional prefects and mayors).

\section{International missions}

The gendarmeries of Francophone African countries are increasingly taking part in international peacekeeping missions. They are viewed as increasingly important instruments in addressing internal security or public order tasks that arise in postconflict environments. Peacekeeping missions have increasingly focused on crowd control, protecting refugees, fighting organised crime and reorganising local police forces, the ultimate objective being not only to destroy an enemy, but to control, or to neutralise those causing trouble. Due to their double affiliation, gendarmerie forces can be deployed both under civilian and under military command. Moreover, their military skills enable them to engage in fighting missions in situations that have deteriorated from post-conflict to war.

\subsection{Are the gendarmerie forces an 'anachronism'?29}

All former French colonies have a dual police system at the national level, with both gendarmeries and police forces. To a number of observers the gendarmerie forces are seen as something of an anachronism, or anomaly, since they represent the continuation of a military presence in domestic security, and therefore legitimise the involvement of the armed forces in internal security matters. The existence of the gendarmerie has been accused of violating the basic principle of the liberal-democratic state that distinguishes between the police and the military. Due to their militarised status, the gendarmeries are sometimes associated with tendencies of authoritarianism. As mentioned above, one of the core problems that is common to a number of Francophone African countries is the insufficient separation and blurred responsibilities between the police and the military forces. Militarised police forces such as the gendarmerie are consequently seen as making this tendency worse. Moreover, the differences that are defined between the police and the gendarmerie lie in their jurisdiction: urban areas as the jurisdiction of the police versus rural areas as the jurisdiction of the gendarmeries. Yet, in a lot of Francophone countries, this distinction is no longer respected.

29 This title refers to the analysis of Bayleys (1985) who view the persistence of the gendarmeries as somewhat of an anachronism.

30 In Côte d'Ivoire, the unity of the armed forces was challenged when the President of the National Assembly, Henri Konan Bédié, seized power after the death of Félix Houphouët Boigny, escorted by the national gendarmerie, whose adherence and loyalty to the law had been crucial until then. The gendarmerie (as well as the police) appeared to be a force loyal to Bédié while the FANCl (Ivorian armed forces), whose general Chief of Staff had been dismissed by him appeared as unreliable. The gendarmerie was seen as a counterweight to the armed forces and was entrusted to keep an eye on them. While the gendarmerie forces are traditionally meant to be equipped with light weapons, the Ivorian gendarmerie is now equipped with tanks and cannons, which were used when General Guei attempted to usurp the elections. Since Laurent Gbagbo came to power, the Ivorian gendarmerie has been accused of being involved in a number of exactions and massacres. A rivalry still exists between the gendarmerie forces, seen as legalist and loyal to President Laurent Gbagbo, and the FANCl, seen as potential conspirators against the regime. 
Nevertheless, despite such criticism, the gendarmerie is often considered as an elite corps: that is why its recruitment may be more stringent than for other services, especially the army. The gendarmes generally enjoy a better reputation than the other security forces: they appear as a disciplined corps that is respectful of the hierarchy. The gendarmerie has generally experienced fewer mutinies than other security forces. More often than not they have not been involved in any forcible takeovers of power. However, in some undemocratic (Côte d'Ivoire) or dictatorial regimes (Guinea), the gendarmeries have been viewed as a central unit that protects the regime, and has sometimes been used as a tool of coercion against opposition movements. In other countries, they are seen as rivals to the army. ${ }^{30}$

A number of Francophone countries have suppressed their gendarmerie forces, as with Belgium in Europe, or Burundi and the DRC in Africa. There is currently a debate in France, where a number of voices have been pleading for the suppression of the gendarmerie in the context of budgetary restrictions which makes the dual police system unaffordable. ${ }^{31}$ Conversely, Switzerland decided to create a gendarmerie-type force in early 2000 .

In contrast, it seems to a number of specialists that there is the growing significance of the intermediary, gendarmerie-type security force. According to them (Lutterbeck 2004), the existence of a gendarmerie actively prevents the militarisation of the civilian police. Furthermore, the emergence of an increasing number of transnational risks and threats that increasingly challenge the traditional distinction between internal and external security have pleaded for the rise of agencies that are located between levels of internal and external security. The distinction between external security on the one hand - identified by a concern with mainly military threats coming from the aggressive behaviour of other states (and captured by strategic studies) and, on the other hand, internal security - identified as criminal, or otherwise disturbing activities, within the boundaries of a state (and captured by criminology or justice studies), have become increasingly blurred. This implies that both crime and war have tended to meet and, consequently, the role of the military and the police forces have increasingly coincided. In a number of aspects, such as with formal affiliation, internal structures and armoury, the gendarmeries occupy an intermediary position between internal and external security forces. The gendarmerie forces are organised along military lines and are thus more centralised and hierarchical than the civilian police forces are; for instance, they are equipped with heavier equipment than common police forces (armoured cars, light infantry weapons). Finally, as mentioned above, the gendarmeries have a double affiliation with the Ministry of Defence and the Ministry of the Interior and are carrying out their police judiciaire missions under the supervision of the Ministry of Justice. In addition to their judiciary and lawenforcement duties, gendarmerie forces have a military defence function (military police, gathering intelligence, protecting sensitive sites) and they perform several more directly combat-related tasks in the event of war.

31 The Swiss gendarmerie-type force is responsible for a number of policy-led functions such as border control, riot control, public order and law enforcement and would, although formally part of the armed forces, be mainly answerable to the Ministry of the Interior. Similarly, a number of former communist states in Eastern and Central Europe have begun to transform their formerly military border guards into gendarmerie-type forces, in order to fight cross-border crime and illegal immigration. 
Due to the fact that they combine both the characteristics of police and military forces, the gendarmeries are viewed by some observers as particularly appropriate institutions to deal with challenges that emerge in Africa. They are seen as a relevant force that can easily be mobilised to deal with:

- border control to counter various transnational challenges. Gendarmerie forces are increasingly mobilised in border enforcement, sometimes along with the armed forces. The gendarmerie has been increasingly deployed towards border areas, and has become involved in fighting arms and drug trafficking. As opposed to the civilian-style police forces, the reason why the gendarmerie forces are considered more suitable to cope with these new missions lies in the supposedly dangerous nature of the operations of the transnational criminal organisations across the borders. The zaraguinas, which operate in CAR, Chad and Cameroon, who are now spreading over the borders are a good example of this phenomenon;

- peace operations, especially in attempts at post-war reconstruction..$^{32}$ The growing importance of the gendarmerie in peacekeeping missions suggests that the gendarmerie could contribute to peacekeeping in accordance with two different formats: a civilian format on the one hand, consisting of securing the theatre of operations; and a military format on the other hand, which would consist of creating inter-African military police units within the regional African stand-by forces. African crises are often characterised by the gravity of the offences and crimes that have been committed, mostly against civilians, by troublemakers; it has been suggested that the gendarmerie forces could act as judiciary auxiliaries to the International Criminal Court.

Such views have inspired a new project: the OGA (Organisation des gendarmeries Africaines - African gendarmeries organisation). A Convention setting up the OGA was signed and adopted by a number of Francophone African countries belonging to three different areas in Francophone Africa: (1) North (Maghreb, Mali and Niger); (2) Western Africa countries (Senegal, Côte d'Ivoire, Togo, Benin, Burkina Faso, Guinea); and (3) Eastern and Central Africa (Chad, RCA, Cameroon, Congo, Gabon, Djibouti and Madagascar). ${ }^{33}$ Senegal is welcoming the Secretariat of the OGA; the Senegalese Gendarmerie High Commander is currently entrusted with the function of OGA's Secretary. On 20 June 2006, the French Minister of the Interior officially announced that France was willing to support the setting up of an African gendarmerie force, similar to the European gendarmerie force, which was launched within the framework of the ESDP (European Security and Defence Policy) (Franceschi 2006, 2007).

\subsubsection{The intelligence services}

Not much is known about the intelligence agencies in Francophone Africa. However, it is worth noting that their structures and functions are inspired by the

32 To some observers, post-conflict contexts can be seen as comparable to the internal turmoil experienced by a number of European states during their nation-building processes, which led governments to set up gendarmeries. 
French intelligence services, which have often assisted their implementation and have ensured the training of their staff. More often than not, French intelligence officers ran these services during the 1980s.

Generally, several services handle the collection of intelligence within the Ministry of Defence and within the Ministry of the Interior.

Within the Ministry of Defence, different Directorates generally handle the collection of intelligence: on the one hand, the Directorate for External Security (Direction générale de la sécurité extérieure - DGSE) is in charge of gathering and analysing information relating to the security of the national territory; on the other hand, the Directorate for military intelligence (Direction du renseignement militaire - DRM) which is responsible to the General Staff, watches over the protection of materials, staff and the installation of the National Defence apparatus, against any hostile action or outside intervention. This office also collects military information for the units that have engagements on the ground.

In the national police forces (themselves part of the Ministry of the Interior as mentioned above), there are also two services that are in charge of the collection of intelligence: the General Intelligence (renseignements generaux - commonly known as the RG); and the services of the territory surveillance (Direction de la surveillance du territoire - DST). ${ }^{34}$ The search for information by the General Intelligence service (RG) is, in essence, different from the type of information looked for by the DST. The DST is an intelligence police service which supplies defence intelligence that intends to discover the activities that are inspired, engaged or supported by foreign states. The RG is more specialised in focusing on internal political matters, especially on political opponents whether they are domestic or exiled.

For the most part, the intelligence services are another tool of political regimes. A defining feature of the intelligence services in Francophone Africa is that there has never been a tradition of effective oversight developed by the Parliaments, even when provisions exist within the Constitutions.

\subsubsection{The paramilitary security services: customs}

In Francophone Africa, customs services generally come under the responsibility of the Ministry of Finance. They constitute a paramilitary body, that fall both under the general statute of the public administration (civil status) and the military. These are generally headed by a General Director, who has been appointed by decree and is assisted by a deputy. The General Directorate is made up of several directorates (central services), which themselves are sub-divided into subdirectorates, desks and sections. The existing directorates are collectively made up as follows:

- the legislation and customs techniques Directorate;

- the Human Resources Directorate;

- the customs receipts Directorate; 
- the information and customs investigations Directorate;

- the data processing Directorate;

- the statistics and economic studies Directorate;

- the external services directorate: these external services have territorial competency and are generally divided between services that are involved in commercial operations and with services that are involved in surveillance of the territory.

The customs services contribute to the definition of national policy taxation and the implementation of it. Their mission is both fiscal and economic. Moreover, the customs services have a role in security matters. This is accomplished by fighting against fraud and the illegal importation of drugs, controlling the import of arms and ammunition, as well as the identification of people at frontiers. The customs services personnel are made up of two bodies:

- the sedentary body (Inspectors and controllers);

- the active body (officers and deputy-officers).

Customs services have thus got a close relationship with the border police who are in charge of coordinating security and surveillance activities that relate to migrations along the territorial, aerial and maritime borders of countries. Finally, the customs services have a national defence mission: they are meant to militarily contribute to the protection and defence of national territory.

Nowadays, the influence of the regional organisations (CEDEAO, UEMOA, CEMAC, CEEAC) increasingly restricts the role of national customs services.

With regards to manpower, the customs services are generally understaffed: with for instance 2,300 agents in Côte d'Ivoire; 1,164 in Burkina Faso; and 480 agents in CAR.

Customs officers generally have a very bad reputation and are seen as highly corrupt.

\subsubsection{Private security companies}

Due to the limitations and/or ineffectiveness of the public security forces, private security companies have proliferated in Francophone Africa in the last few years.

Firstly, it is important to stress the fact that private security has traditionally been assimilated to the major influences that French or Belgian mercenaries - the most famous of them being Bob Denard, Schramme, Tavernier and Hoare - have had over security in Africa. These mercenaries were the same ageing fighters, the same reserve officers, the same ex-non-commissioned officers of Belgian commando groups, or from the French Foreign Legion. Their inexperience, and their poor equipment, explains the mediocre quality of their numerous performances and their bad reputation.

Mercenaries of African origin have also been active in Francophone Africa including in recent times. In 1997, in the former Zaire where President Joseph 
Mobutu faced the armed rebellion led by Laurent-Désiré Kabila, a majority of South African, Togolese and Angolan elements were identified. In 2002, Liberian mercenaries supported the regime of General Robert Guéï in Côte d'Ivoire. Mercenaries from Eastern and Central Europe have also been active in Francophone Africa. In August 2004, President Gbagbo engaged Ukrainian hunting pilots: besides the technical aid for the benefit of the Air Force, they were brought in to directly assemble military operations on the ground, especially during the bombardments of Zouan, Vavoua, and Gohitfala.

Finally, French former members of the special forces, the elite units, the gendarmerie, the Foreign Legion, the intelligence services, certain parachutist regiments - or of the Department of Protection and Security (DPS) of the National Front - participated in operations in Zaire (in 1997 and 2001), Madagascar (2002) and in Côte d'Ivoire (2001-03).

However, from the mid-1990s (Leymarie 2004) onwards a new kind of private security service has been emerging. There is a need to make a clear distinction between the traditional mercenary organisations described above - whose members are used to fighting in wars and overthrowing governments - and the new private security companies which are increasingly operating as adjuncts to governments to provide both advice and assistance on military/security matters. These new kinds of private security companies can be found in democratic Francophone countries as well as in dictatorial regimes. The distinctive characteristics of the contemporary Anglo-Saxon PMCs (private military companies) can only be applied with difficulty to private companies operating in Francophone Africa. These structures remain small in size and are often highly specialised. A number of those private security companies involve high ranking, retired, French military officers (often former gendarmes, the most famous being Paul Barril, ${ }^{35}$ Philippe Legorjus, ${ }^{36}$ Robert Montoya ${ }^{37}$ and Jeannou Lacaze) $)^{38}$ and sometimes their

35 Paul Barril's employees spoke about him in the autumn of 2002, during a crisis in the Central African Republic. This former gendarme created the Group Barril Sécurite after a career within the GIGN. The Group Barril Sécurité includes several companies: Barril Investigation, Protection Conseil Sécurité, Groupe Privé Barril, Activités sécuritaires, Security Action Store, Haute Protection. The Group Barril Sécurité proposes several types of services: audit, and the detection of listening, close protection, investigations, engineering, management of crises (among the crises, Paul Barril quotes 'media campaign of malicious gossip, blackmail, threats, detention, disappearance, kidnapping, judiciary problems, terrorist threats, training and recruitment'). whose purpose was to 'accompany French companies in at risk zones to reassure their logistic and financial operations'. The company Total is amongst his customers. In 1995, he created Atlantic Intelligence, which specialised in economic intelligence.

37 Robert Montoya also moved into private security after a career in the gendarmerie. He was very active in Francophone Africa, through the group SAS (Security and Advisory Service), and owns the GéodisCalberson group, which was SAS' first customer. Robert Montoya also leads Darkwood Logistique, a transport company based in Togo. Today, Robert Montoya leads more than 2,500 people in seven countries and proposes missions of advice and audit, security of persons and goods, airport security, security of airline companies, accompanying export, and economic information.

38 Jeannou Lacaze is the late joint Chief of Staff of the French military. The Lacaze's group SAS International employs about 2,500 people, and generally ensures the security of heads of states and their families. 
African counterparts. Some of these men were, for a long time, bound to the French secret services; some became free to propose their services to big companies or to African States. As they cannot rely on important governmental contracts (the French government being traditionally very reluctant to officially resort to their services), the French companies have directed their activities towards commercial customers (private enterprises) and private customers (businessmen, diplomats, VIPS). The services that are offered by French companies vary from close protection, training, risk management and economic intelligence, to the protection of sites and mine clearance. The customers are made up mainly of companies (Elf, Bouygues and Total are among the most important). The services are often entrusted to former soldiers but without real military implication. However, some of these companies sometimes offer discreet training to African armed forces (instructions on shooting, training of specialised, technical units of intervention): Robert Montoya's company, SAS (Security Advisory and Service), for instance, was particularly active in Togo (training and equipment of the anti-riot forces of the General Eyadéma regime), in Zaire and in the Gabon. Eric Sa's company can be seen as the closest to mercenary activities but on a small scale. Finally, two small private companies show their ambition to compete with the Anglo-Saxon PMC:

- The group Earthwind Holding Corporation (EHC), created in 1999 and based in Luxemburg, offers strategic and confidential advice to security services for companies abroad, supporting international institutions and NGOs, training, instruction and support for armed forces. ${ }^{39}$ Another branch of EHC is the representative of the Northbridge Services Group, a British PMC, involved in several projects in Africa (peace enforcement in the RDC, arrest of the Liberian Charles Taylor, reassurance in Nigeria). Northbridge is therefore there to recruit French-speaking staff via EHC.

- Secopex, created in May, 2003 by former non-commissioned officers of the parachutist regiment of the marines, 'proposes a French alternative to AngloSaxon know-how and is represented by the multiple American, British or South African private military companies'.

Finally, in all Francophone countries can be found a growing number of private companies who mainly specialise in security guard provision. The growing number of these kinds of private companies illustrates perfectly the growth of the demand for protection services. A lot of African demobilised soldiers are employed by these companies. In most Francophone African countries, these companies are generally owned by French Nationals and sometimes by Lebanese individuals. Even public organisations rely on their services. Some companies are also increasingly active in humanitarian mine clearance. For instance, the IIC (International Instruction Corps) have been on missions to clear mines in the Central African Republic, and in Mauritania.

In some countries, (Mali, Cameroon) private security companies are only allowed to carry out their activities if given an allowance by the Minister of Internal Security. However, in most of the countries, there are no laws, decrees, licensing, or provisions of the criminal code which govern the activities of the private security

39 Amongst its leaders, we find former executives of the French armed forces. One of them was involved in several mercenary operations in Africa. 
companies in Francophone African states: denomination of private companies, kind of activities allowed (for instance, prohibition from maintaining order, from providing surveillance linked to political and religious opinions, from preventing freedom of movements of persons and vehicles), right to bear arms (which category of weapons); and kinds of uniform, are not legally defined.

\subsubsection{Vigilante groups and non-state security actors}

During the conflicts of the last two decades, private militias emerged in some countries. In some of these countries, such as Niger and Mali, self-defence groups were set up in nomadic areas in order to protect the nomadic population from attacks and violent aggression. These self-defence groups were not provided by a reliable security firm or by the State. The people in these regions organised themselves into groups to protect their property (Arab, Tuaregs and Peulhs communities). These groups have now developed a loose collaboration with the forces of law and order. In rural areas of CAR, villagers organised themselves into self-protection units in order to protect their communities from the attacks launched by rebel groups, governmental forces or organised criminals. Following the reduction of the budget of the national security forces, the inhabitants of urban centres have similarly paid individuals to ensure their protection.

In addition, on the margins of the state, another kind of militia has emerged in a number of the Francophone countries: involving both criminal groups (e.g. coupeurs de route, gangs) and security officials (customs and police officers), these militias illustrate the rise of informal networks which thwart the formal structures that are supposed to be in place. For instance, the coupeurs de route phenomenon appeared in Cameroon during the 1980s. Initially very sporadic and limited to the extreme north, the north and the Adamaoua regions, it has tended to extend during the past few years, to other parts of the country, particularly the east, the west and the centre (Fogue 2007; Roitman 2004). This phenomenon has been expanding due to Cameroon's economic situation, and to the chronic instability in its neighbouring countries, particularly in CAR and Chad and, to a lesser extent, in Nigeria. The CAR's 'zaraguinas' (as Central Africans call the coupeurs de route) are more and more of a presence in the northern and eastern parts of Cameroon.

The coupeurs de route is both a rural and urban phenomenon. The coupeurs de route operate along roads, as well as at the boundaries of towns and villages. This phenomenon is closely linked to trans-border insecurity and to the circulation of light weapons. Generally made up of 3 to 30 members, these groups sometimes operate with the complicity of the population. Ambush, disembowelment of domestic cattle, kidnapping, holdups, and murders are their main modes of operating. Initially led by amateurs, who were unskilled and mostly unemployed young people, these attacks have been increasingly set up by professionals. A number of deserter soldiers as well as some former rebel group combatants operating in Chad and CAR, have switched to this new occupation and have joined coupeurs de route groups. The porosity of the borders enables them to operate on the territories of the three countries. The coupeurs de route have been able to obtain very sophisticated equipment (e.g. satellite transmission equipment, war weapons) which strengthens their operational capabilities. They also specialise 
increasingly in gun trafficking. The coupeurs de route phenomenon has resulted in important population displacements, infrastructure destruction, as well as the looting of wildlife and terrorising of the population. A lot of people have been reported dead after attacks led by the coupeurs de route (111 from January to August 2007). The cross-border dynamics of this phenomenon confer it to a subregional dimension.

\subsubsection{Funding provisions}

There are a lot of commonalities between the French ${ }^{40}$ and the Francophone public expenditure management (PEM) systems in terms of legal settings, rules and procedures. However, there are marked differences in audit and external controls between Francophone states (Abdourahmane and Crouzel 2004; Sangaré 2006). According to a survey led by the IMF (Yaya 2004), Francophone African countries share roughly 57 per cent to 74 per cent of the French public expenditure management system: Benin is the closest to France, followed by Côte d'Ivoire and Mali, while Congo and Togo reflect the greatest differences. The commonality between the French system and the Francophone African states is very strong with regards to the cash plan, the description of expenditure processes and internal control. But there are marked differences with audit and external control, on accounting and on reporting systems.

\subsubsection{The legal and institutional environment of budgeting}

In France, as in most Francophone African countries, Parliament has the first and last word with regard to the use of public money. The approval of the budget by Parliament is a prerequisite for the executive branch to use public money.

The vote by Parliament authorises the executive branch to spend through appropriations of credits. There are three broad categories of appropriations: the most common category is the capped appropriations (crédits limitatifs): as a general rule, spending commitments and orders to pay are capped by the budget law. The next two types of appropriations are exceptions and their amounts are provisional. The first type is the provisional appropriations (crédits provisionnels). The government can supplement these appropriations from other sources. A typical case is the spending necessitated by natural disasters. The second type of exceptional appropriations is the estimated appropriations (crédits évaluatifs). The budget figures are only estimated and they can be increased (through debt repayment and litigation costs): the defence budget often comes from this category.

Furthermore, the budgeting process is embedded in four key principles:

- unity: the budget should contain all government revenues and expenditures, even if three different parts - general budget, ancillary (budgets annexes) and Treasury special accounts (comptes spéciaux du Trésor) - detail the content of the budget better and constitute the budget law; 
- annuality: the budget is approved and executed on an annual basis;

- universality: all government revenues and expenditures are incorporated in the budget

- specialty, which allows Parliament to authorise the executive branch to spend not just the overall budget, but specified categories of credit, which is categorised by ministries.

The central principle of a treasury single account ensures that the government, via the Treasury, concentrates its cash resources into one account, usually held at the Central Bank. Local governments and public agencies should then deposit all their funds with the Treasury. Hence, the Treasury is a pool emanating from different entities. The unicity of the cash desk (unité de caisse) is the corollary.

Different actors are involved in the budgeting process. The executive branch, notably the Minister of Finance, under the supervision of the prime minister, prepares a draft budget after consultation with the ministries who are doing the spending. The budget is executed by the executive branch through four main phases: engagement (origination of the spending), liquidation (validation of the expenditure), ordonnancement (order to pay) and payment (disbursement of money to honour the government's engagement). The ex-post control is performed by the Parliament and by the Public Audit Office (Cour des Comptes). There is a strict segregation of duties between those who administer budget appropriation and those who actually manipulate the cash. The first three functions (engagement, liquidation and ordonnancement) are carried out by the ordonnateurs whereas the last one is carried out by the comptable or public accountant. This segregation establishes a mechanism of mutual control between those who commit the government and those who make the actual payment.

However, this PEM system is subject to two main exceptions which allow the executive branch to bypass Parliament on budgetary matters in specific exceptional circumstances:

- government secret funds (fonds spéciaux) which the government doesn't have to justify and usually relates to national security matters;

- the cash advance funds (régies d'avance) which, for practical reasons, are designed to remedy the lengthy spending procedures.

\subsubsection{Control of budget execution}

There are three types of budget control:

- administrative control by the administration of internal bodies. Internally, these controls are operated by the financial controller at the origination phase of the spending process (engagement), and by the accountant at the payment phase (paiement). Spending ministries also have their own internal controlling bodies. These administrative controls are meant to check that laws and regulations are complied with;

- parliamentary control exercised by Parliament. Parliamentary control is external. The control prerogatives of Parliament are defined by the 
Constitution. Three types of budget law are passed by the Parliament: the initial budget law (loi de finance initiale), which includes all annual government revenues and expenditures; the supplementary budget law (Ioi de finance rectificative), which modifies the initial budget during its execution; and the budget review law (loi de règlement), which reconciles the executed budget with the initial budget following the closure of the fiscal year, and certifies that the budget has been executed in conformity with prior legislative authorisations. Besides these, Parliament can also set up ad hoc committees to investigate any misuse of public money by the executive branch. In fact, the control of the executed budget by Parliament remains largely symbolic: the Parliament can only validate the reconciliation of the accounts that have already been carried out;

- jurisdictional control carried out by the Public Audit Office (Cour des Comptes). The Cour des Comptes is an independent jurisdiction taken from both the executive and the legislative branches of government. Its attributes are defined by the Constitution. It performs financial audits (accounts held by the public accountants) as well as performance audits (observance of the principles of economy, effectiveness and efficiency in the use of public money). The Public Audit Office also audits agencies that benefit from government funding. However, it has no control over credit managers: it judges the accounts, not the accountants.

The a priori controls of the first (origination) and last (payment) phases of the expenditure process are a key feature of the French PEM system. Conversely, the control of the executed budget by the Parliament is in fact mostly symbolic, given that the Parliament only validates the reconciliation of the accounts already carried out by the account-centralising body within the Ministry of Finance on the one hand and by the Public Office of Account on the other hand.

Finally, there is the unlimited responsibility of public accountants (who are personally financially responsible for any irregularities in the management of funds that they are entrusted with); whilst the ordonnateur, ${ }^{41}$ auditor, (who can administer credits and gives orders for payments) enjoys partial immunity. Consequently, ministers and elected officials are not subject to the Budgetary and Financial Discipline Court, which comprises magistrates of the Public Account Office and members of the State Council (Conseil d'Etat). Ministers cannot be tried in court, whereas members of their cabinet and other civil servants can be legally prosecuted. Furthermore, an adverse judgement does not generally imply the repair of financial prejudices. Sanctions are mostly symbolic and based on reputations.

\subsubsection{Commonalities and differences between the French system and African Francophone countries}

The similarities between the French system and the systems of the Francophone African countries are very strong with regard to their cash plans and their outlines of the process and internal control of expenditure. Francophone African countries are similar to France in their legal and institutional ways of budgeting, for instance 
the control of government by Parliament through the voting of budget law; supplementary budget review laws and budget review laws with an adherence to a deadline for the formulation and execution of budgets. Moreover, Francophone countries are similar to France with regards to: their expenditure processes that follow the engagement/liquidation/ordonnacement/payment phases; the a priori control by the financial controller at the level of engagement; the a priori control performed by the public accountant; the distinction between the ordonnateur who can give the order to pay out, and the accountant who actually does the paying; the deadline for committing the government, and for ordering payments during a fiscal year; the liquidation phase and the expenditure procedures that are simplified for petty cash spending.

However, although Francophone African countries have historically borrowed largely from the French budgeting system, they have in practice departed from the original model. There are a lot of differences between France and Francophone African countries in auditing, in external control, in accounting and in reporting. Although budgeting control institutions exist on paper, in practice they work very poorly. The parliament budgetary role is very weak and their budgetary prerogatives (vote of initial, supplementary and review budget laws, as well as control of the executive branches) are, in fact, largely symbolic. Most of the time, it is very difficult to clearly appraise the amount of the security budget since this is divided between several governmental bodies and policy areas. The Francophone African countries are very different from France with regards to the ordonnateur and of the degree of consolidation of the budget. Most of the Francophone African states generally do have a centralised structure with an ordonnnateur unique who often is part of the Ministry of Finance, while in France all Ministers are ordonnateurs for spending by their ministries. The monopoly that is held by the Ministry of Finance is a defining feature of systems in Francophone Africa.

Furthermore, there is another distinctive feature with regards to the defence sector: in a lot of countries, the Ministry of Defence does not have any control over the defence budget. It is the President, rather than the Ministry of Defence, who considers the budget as his monopoly and can give payment orders (even for minor expenses such as fuel and ammunitions), managing the budget completely under secretive rules. Consequently, exceptional spending procedures are often overused.

Besides, in Francophone Africa it is only the central Government's operations that are mostly recorded and budget consolidation is therefore very weak. The differences with France are particularly striking with regard to fiscal reporting and budgetary computerisation. In a lot of Francophone countries consolidated treasury balances are not frequent and budget construction is mostly manual. In the best case scenario, executed budgets are published with very long delays (often more than five years after their closing date). Long delays are also observed in voting on the budget review laws. The information flow between the budget Directorate and the treasury is irregular. And, as a consequence of a badly monitored execution budget, the Treasury's data is often incomplete or incorrect.

In practice, normal budget processes are often bypassed and often recourse is made to exceptional spending procedures: these are particularly widespread in the defence sector where spending rules are often circumvented, while extra- 
budgetary spending and political interference is more frequent. The real levels of payment are difficult to assess, due to the length of administrative spending processes and the lack of efficient control. The reliability of fiscal data is also often questionable.

Finally, audit and external controls are the weakest links of the Francophone PEM systems. In many African countries the supreme audit institutions are either quite recently formed or they do not exist, in spite of Constitutional provisions that mention such offices. Public audit offices in Cameroon, the DRC and the CAR have been created but are not operational. Where they do exist, public audit offices are ill-equipped and under-staffed and do not have skilled members of staff. Most importantly, Government auditors are not independent from the executive branch, except in Senegal. Government accounts are rarely checked by the supreme audit institution. In countries such as Chad, Cameroon and Togo, the accounts have never been verified.

In fact, Francophone African countries have imported the French budgeting system without the required human and technical capacities. While France itself is now moving towards a new budgeting system (the New Organic Budget Law), Francophone African countries also need to devise budgeting systems tailored to their specific needs. To do so, it is more than urgent in these countries to develop a better knowledge of the informal processes in which budgeting processes are rooted.

\subsection{Research on Security Sector Reform (SSR) in Francophone Africa}

Carrying out documentary research into institutional security development in Francophone Africa is a real challenge: there is little information and few materials - either at primary and secondary source that are available in the public domain. Only a few states have compiled the statutory rules of their Public Service, and texts relating to the special statute that characterise most of the defence and security forces in Francophone African states are unavailable. As a consequence, priority must be given to European or North American research or documentation centres when carrying out documentary research into the security sector of an African Francophone country. In addition, there are no organised SSR-focused research capabilities of any importance that can be identified in Francophone Africa. Individual academics - rather than research centres, networks or think tanks - are working on SSR topics in isolation. However, it is important to note that these people, if not numerous, do generally have a very deep understanding of the African Francophone security systems (see for instance N'Diaye 2007; Agokla 2010; Sangaré 2006; Toulabor 2005; Bryden 2008; Petiteville 1996). Most of the time, these individuals belong to research centres that are specialised in international relations, strategic studies or geopolitics. A lot of Francophone practitioners have also developed very specialised skills in the field of security reform. If connected to a strong network, these academics and practitioners could bring invaluable contributions to the SSR in Francophone Africa.

It is important to acknowledge the fact that there are difficulties in conducting research in most of Africa; most singularly, Francophone Africa constitutes in some cases, a wilful obstacle to knowledge production for analysis and sound 
policy formulation. It is in itself a major hurdle to the improvement of security provision, and stability. Furthermore, the 'secrets' that these practices are supposed to protect are often common knowledge.

\subsection{Military schools and police academies in Francophone Africa}

In Francophone Africa, a very strong network of military schools and police academies has been implemented. Of special interest is the concept of ENVR (Ecoles nationales a vocation regionale - National schools with regional vocation). The ENVR concept was first launched in the 1980s by the French military cooperation services; it was renewed in 1998. The ENVR aim is to adapt the training that is traditionally given in French military schools to the particularities of the African continent..$^{42}$ Moreover, the scarce resources of the African countries are less and less likely to provide the funding necessary to support national specialised schools: the ENVR aims to mutualise the costs of training, by avoiding duplications.

The ENVR are meant to welcome trainees who come from all Francophone countries; they promote a regional approach to security on the continent. French coopérants always define the training curriculum and head up the division of study. 25 per cent to 50 per cent of the available positions are booked for trainees who originate from the host nation. Trainees have to pass an entrance examination to have access to the schools. Some of these schools are called upon to work closely with regional organisations and with the African Union (AU) and to become excellence training centres for the $A U$ stand-by brigades in the long run.

Currently, there are 14 ENVRs in Africa, located in ten Francophone countries: Benin, Burkina Faso, Mali, Niger, Senegal, and Togo in West Africa, and Cameroon and Gabon in Central Africa. There are three major kinds of training:

- military general training;

- support of peace operations;

- $\quad$ specialised training.

Fifty different types of training are proposed in the 14 ENVRs (see Annex). A number of these training areas are bilingual (French/English).

Trainees come from 31 African countries: even if the ENVR mainly welcomes Francophone trainees, they are increasingly welcoming trainees from Anglophone countries (Nigeria, Ghana, Kenya, Tanzania) and Lusophone (Angola, Mozambique) Africa. In addition to the ENVR, a growing number of national schools welcome trainees from other Francophone countries.

Two other ENVRs are about to be set up: the High Joint Defence Training Centre (Cours supérieur Interarmées de Défense) in Yaoundé (Cameroon) and the Transmission School in Manea (Guinea).

42 France then decided to welcome fewer African trainees into its own military schools. 


\section{Comparison between security systems in Francophone and Anglophone Africa}

This section aims to provide a better understanding of the institutional, bureaucratic and legal security arrangements operating in Francophone and Anglophone African countries, highlighting their commonalities and differences. This section does not attempt to provide a performance rating of Francophone and Anglophone security apparatus nor does it define performance benchmarks against which security apparatus should be systematically assessed. It only consists of a general overview presenting the core differences between security systems in Francophone and Anglophone African countries.

Those differences, developed below in more detail, can be summarised as follows:

- The ability to enact SSR in the absence of broader governance reforms frameworks (such as public sector reform structures) in many Francophone African countries;

- The different level of influence of the former colonial powers in the governance of the security sector, France having been much more involved in the management of the security apparatus of its former colonies than the UK;

- The absence of national security councils in Francophone Africa similar to those that can be found in an important number of Anglophone countries;

- The important role of civilian bureaucracies within a number of Ministries of Defence in Anglophone countries with no equivalent in Francophone Africa;

- The improvement and growing professionalisation of military justice in an important number of Anglophone countries whilst only a few number of Francophone countries have addressed this challenge;

- The fact that it is acceptable in Francophone countries for the military to be involved in humanitarian or development projects;

- The existence of armed forces (such as the National Guard and gendarmeries) with no counterparts in Anglophone countries: those forces, particularly the gendarmeries, are institutionally endowed with police missions;

- The introduction of sector-wide budgets for security in some Anglophone countries;

- The introduction of oversight mechanisms of the intelligence services in South Africa with no equivalent in most of the other African countries, be they Francophone or Anglophone;

- The institutionalisation of a strong research and expertise capacity on SSRrelated issues in Anglophone Africa whilst Francophone expertise is fragmented and carried out outside any structured networks;

- The existence in Francophone Africa of a large network of military schools and police academies which are welcoming trainees at the regional level. 


\subsection{Security reforms in Francophone and Anglophone Africa ${ }^{43}$}

There are currently no military regimes in Anglophone countries in the region, although the military still plays an important role in governance and the economy, as many of the civilian leaders and business elites are either former military officers or ex-guerrilla fighters (Cawthra 2003; Ebo 2005; Edigheji 2005; Howe 2000; Ibrahim 2003). The transition to democracy in Nigeria in 1999 marked the end of direct military rule in Anglophone Africa. This is a major difference with Francophone Africa where unconstitutional changes of government driven or supported by the military have recently proliferated (cf. above: Mauritania, Guinea and Madagascar). Nigeria, Kenya, Ghana, Mauritius and Uganda have evolved over time into relatively mature and sophisticated security forces by regional standards. In Ethiopia, the original security structures with Marxist leanings have been ideologically transformed to fit into a neoliberal state. In Eritrea (which broke away from Ethiopia in 1993) the guerrilla forces have been re-organised and modernised into modern military and police forces. South Africa has been able to reform the defence and security forces inherited from the apartheid regimes in order to integrate former rival combatants (Hughes 2007; Rupiya 2005).

Furthermore, whilst a number of Anglophone African countries have entered a process of reform, Francophone African countries have barely experienced any significant transformation in security governance. Anglophone countries have arguably been more open to changes in the direction of increased accountability (Ministries of Defence relatively independent from the armed forces; parliamentarian oversight; accountability to audit bodies, ombudsman, human rights commissions, etc.) than their Francophone equivalents. This may partly reflect variations in their respective democratic transition processes. ${ }^{44}$ But another factor has been the active promotion of SSR itself in Anglophone countries by bilateral donors (especially by the UK) - together with some cross-fertilisation among Anglophone countries (led by non-state organisations such as ASSN, SADESM etc), as well as the effects of the South African model. In a few countries where institutional neglect has led to institutional criminalisation and decomposition, and leading to the eventual collapse of the state itself, security structures are being reconstituted within the rubric of post-war reconstruction under the tutelage of international or regional actors. This is the case in Sierra

43 The author wishes to thank Jeffrey Isima for the very useful inputs on the security sector in Anglophone Africa that he has provided.

44 While periodic elections are held in all of these countries, there are marked diversities in Anglophone Africa, in terms of the substance of democratic governance, ranging from consolidating democracies at the upper echelon to electoral civilian autocracies, such as Zimbabwe and Eritrea at the bottom of the ladder. The most glaring example of a consolidating democracy, in terms of institution density and governance processes, is South Africa. Others not too far behind are Ghana, Tanzania and Mauritius. Countries where the democratisation project is progressing are Nigeria, Zambia and Malawi. In a number of other countries, democratisation has been blocked by the regime itself, especially those regimes that have stayed in power for long periods. Examples are Namibia, Uganda, Botswana, Sudan and Ethiopia, where a multiparty constitution is in place, but the ruler's party has remained in power for decades within the framework of democratic rule. The significant rise in the role of military and security forces in politics in some other countries with a history of prolonged military rule (such as Nigeria) has consequently ensured that the transition to democracy is being manipulated, or even initiated, for the political survival of rulers with deep roots in the military. 
Leone and Liberia (Aboagye 2005), where the main security forces have been overwhelmed by social forces and de-legitimised by their infamous roles during the war, and are therefore being transformed into more effective, accountable and professional forces in a democratic environment. ${ }^{45}$ Stable countries such as Ghana have also experienced a noticeable improvement of security governance. The situation is of course far from ideal: in a lot of countries, security ministries still tend to be weak and badly resourced; the mechanisms of 'horizontal' accountability - to audit bodies, ombudsmen, human rights commissions, etc. are weak in essence whilst military forces have fared better than the police forces. But it cannot be denied that security governance has been improving in an important number of Anglophone countries over the last few years.

As mentioned above, Francophone African countries are usually presented as not having experienced any significant transformation in security governance. The seizure of power by the military - or with their complicity - in several States (Mauritania, Guinea, and Madagascar) is seen as dramatic evidence of the total lack of improvement in security governance. However, the situation is much more complex. It is important to be aware that, in fact, a rather important number of countries, including non-democratic ones, have entered stealthily into a process of reform. Most of the time, these reform processes have been undertaken and framed without the SSR label. A number of reform processes have been launched at the initiative of national authorities and they are undoubtedly resulting in more professional and more accountable security forces, which is the overarching purpose of the SSR approach. In Mali, security sector functioning has been improved in terms of oversight and supervision (especially as regards budgeting processes) and the armed forces are becoming more professional. Senegal where the armed forces have clearly improved their professional skills and their democratic behaviour (thanks in part to their participation in peacekeeping missions) since the early 1960 s - is also interesting, even if the reform process has been to a large extent limited to the armed forces, whilst the police sector has been left behind and the oversight and supervision mechanisms (parliaments, ombudsmen, audit account) are increasingly weak. The case of Togo is a very telling example of security reform processes occurring in non-democratic environments (UNREC 2008).

In addition, three Francophone countries (two former Belgian colonies and one former French colony) have entered into ambitious security reform processes, under the pressure of the international community:

- the DRC, where security structures have entered a huge process of reform (the outcome of which is, however, very uncertain);

- Burundi;

- the Central African Republic, where the reform process is the first example of a holistic approach to SSR.

45 Liberia and Sierra Leone have national structures in charge of state reform. The Liberian Governance Reform Commission was established by the Comprehensive Peace Agreement of 2003, which ended the war in that country. This Commission which was established to promote the principles of good governance, is independent, being made up of seven permanent members appointed by a Chairman who is from civil society. In Sierra Leone, a Governance Reform Secretariat was established as part of the Ministry for Presidential Affairs to coordinate all governance reform initiatives (Gbla 2007). 
In these countries, however, SSR processes seem to be disconnected from the more global public reforms, contrary to what can be found in some post-conflict Anglophone countries.

\subsubsection{Legacy of the colonial and post-colonial order}

It is possible to identify distinct Anglophone and Francophone institutional patterns of security sector governance, rooted in colonial legacies (Rouvez 1994; Somerville 1990) as well as in ongoing relationships with the ex-colonial power.

\subsubsection{Type of presence}

A major difference between Francophone and Anglophone Africa is the degree of involvement by the former colonial powers in the governance of security structures during the post-colonial area.

For the most part, the British, unlike the French (see Section 2.2), withdrew from close security relationships with their ex-colonies soon after independence. In some countries, the British were in fact pushed out (the abrogation of defence agreements by Ghana and Nigeria, for instance). The British support most of the time took the form of periodic interventions by the BMATT (British Military Advisory Training Team). Only a few long-standing arrangements - like British support for the Command and Staff College in Ghana - can be mentioned. Kenya, however, is a specific case, as British security involvement arguably continued postindependence to a greater extent than in other ex-British countries. A trend toward more multilateral forms of support has been inaugurated by the British support for peacekeeping training in the Kofi Annan Centre. The UK's recent SSR and postconflict involvements have partly altered this situation, committing it to a much higher level of security engagement than at any time since the 1960s. In Sierra Leone, the UK has reverted to something much closer to French levels of engagement. ${ }^{46}$ Finally, British support to SSR can be viewed as part of such a reengagement: SSR programmes tended to reflect and promote British and wider Commonwealth paradigms of security governance. ${ }^{47}$ However, direct British military involvement in Sierra Leone was limited to a few months in 2001 and the BMATT quickly became international (International Military Advisory Training Team - IMATT). SSR programmes have added new forms of engagement to traditional British assistance, aiming not only to train but also to reshape security architectures, improve accountability, strengthen oversight capacities (e.g. of Parliaments), improve budgeting procedures, assist defence and security reviews, etc. SSR programmes imply a deeper level of engagement than the French military presence in Francophone countries, which arguably stabilised existing relationships, rather than seeking to transform them. British engagements in SSR - alongside other donors and international agencies - are new and arguably more intrusive forms of engagement. This change of emphasis has less to do with a

47 In particular, the South African paradigms have been hugely influential, being distinct from the British model, which is much narrower and offers less scope for accountability. 
deeper defence relationship than the arrival of new actors, especially the Department for International Development (DFID) in the security field.

It is also paramount to recognise that French permanent cooperation (as described in Section 2.2) can be seen as a particular approach to SSR, in fact a more traditional one. France has developed a very segmented approach to SSR; there were no links between the reforms allegedly led in the defence, police, justice and customs sectors. Furthermore, French security cooperation has not traditionally been focused on security governance (e.g. role of Parliaments, Audit Accounts, the media, civil societies). France has recently tried to update its approach by publishing its own SSR Manual, inspired by the DAC/OECD principles (www.diplomatie.gouv.fr/en/IMG/pdf/12-Ang-MAEE-RSS-final.pdf, accessed 8 March 2010).

\subsubsection{Types of institutional arrangement}

All Francophone countries have centralised presidential systems, in which security bureaucracies report directly or indirectly to the President. Although Anglophone countries in theory have an inherited tradition of Parliamentary government, in reality Presidential control has prevailed in all of them. In practice, however, in almost all African countries there has been centralisation under Presidential authority. Therefore, the direct Presidential authority and control in security matters cannot be seen as a defining feature of the security architecture in Francophone countries: ${ }^{48}$ in many cases Presidentialism was further reinforced by authoritarian governance and its legacies - in both Anglophone and Francophone countries.

\subsection{The central role of the President}

As mentioned above, in Francophone Africa, a series of post-colonial and policy variables have combined to create a situation whereby the security sector is working alongside structures that were largely inherited from the French model. The legacy of colonialism and then the adoption of Constitutions inspired by the French Fifth Republic Constitution - if not a carbon copy of it - has resulted in a concentration of power in the Executive.

There is more uniformity in the institutional arrangements of the Francophone African states than in Anglophone Africa. It can be argued that British disengagement permitted greater institutional diversity among Anglophone countries, making it harder to discern common trends and patterns among them. Initially, institutional arrangements in most Anglophone countries reflected the distinctively British heritage, e.g. Parliamentary government, common law, sharp separation in principle between external defence and internal policing, and hence between military and police, etc. However, most Anglophone countries have shifted toward Presidential governance, not least in relation to the security sector - hence tending to converge with French-speaking countries where presidentialism was part of the initial colonial legacy. Furthermore, in Anglophone Africa, security governance influences stem from elsewhere than the United 
Kingdom institutional tradition - either from widespread links with other Commonwealth countries (e.g. training of security personnel elsewhere in the Commonwealth) or from the USA - e.g. in Nigeria where the Federal Constitution, Presidential government, the bicameral legislature and its select committees, etc., reflect the US influence even more than the British.

The US influence is of course also paramount in Liberia. More broadly, it is worth noting that constitutional provisions inspired by the US Presidentialist Constitution have been integrated in a number of Anglophone as well as Francophone countries, especially the provision entitling the President of the Republic to be Supreme Chief of the armed forces. Currently nearly all the constitutions in the former British colonies, (with the exception of Ethiopia, Lesotho and Swaziland), have adopted the Presidential system of government, as opposed to the Westminster parliamentary system inherited at independence. This marks a sharp departure from the British tradition and rather adhere to the strong American presidential system in the process of Africanisation. ${ }^{49}$ The Constitutions stipulate that the President is the Commander in Chief of the Armed Forces, and has ultimate powers to determine the operational use of all security forces. The President also appoints the ministers in charge of the Ministries of Defence, Home (Internal) Affairs and Intelligence. The President also has the executive powers to appoint the operational commanders of the security forces such as the Chief of Defence and the service Chiefs in charge of Army, Air and Navy (some countries do not have all three services), as well as the Inspector General of Police (called Commissioner in some countries), and the Inspector General of Intelligence. From this perspective, constitutional frameworks in Anglophone Africa are more than similar to those of Francophone Africa. However, a major difference stems from the existence of collegial organisations meant to be fully associated in the decisionmaking process: in almost all Anglophone countries, the appointments and decisions are supposedly made on the advice of the National Security Council, the Defence Council and the Police Council, which are established to advise the President on policy matters relating to the respective services (see below).

Finally, after independence, influence from the ex-Soviet bloc has been a factor both in several Anglophone countries (Tanzania, Zambia, Uganda, Ethiopia, Namibia, etc.), but also in several Francophone countries (Guinea, Mali, Congo Brazzaville, etc.).

4.1.1.2.2 The absence or weakness of collegial decision-making structures (national security and police councils) in Francophone countries

In almost all Anglophone countries, appointments and decisions are supposedly made on the advice of collegial organisations which are established to advise the President on policy matters relating to security, and consequently have an important role in the policy decision-making process. The Cabinet is the highest decision-making organ of government and this includes national security policy.

49 Yet only a few of these constitutions are popular and uncontroversial. Apart from South Africa, Ghana and Zambia, most current constitutions in Anglophone Africa were written and enacted by outgoing military regimes and single-party dictatorships or civilian autocracies and semi-democracies, all of which have ensured that long-held political and economic prerogatives of past ruling elites are guaranteed under the new 'democratic' dispensation. 
Moreover, from a decade ago, a number of countries have introduced structures and policy review processes (such as Defence Reviews and/or National Security Reviews, White Papers) whilst interagency decision-making structures have been set up. At the top of all national security organisations is the National Security Council (NSC), which coordinates all security policy and advises the President on national security matters. The NSC, which is under the direct control of the Presidency, is managed by a National Security Adviser (as in Nigeria) or a National Security Coordinator (as in Ghana and Sierra Leone). The meetings of the NSC are presided over by the President and are made up of the Ministers of Foreign Affairs, Defence, the Interior, and Finance, and such other Ministers as the President determines. Other members of the NSC are the Chief of Defence Staff (or Force Commander as is known alternatively), the Inspector General of Police and the Directors of the various Intelligence agencies. The influence of these NCSs of course varies from case to case.

Two other important national organisations that can be found in a lot of Anglophone countries are the Defence Council and the Police Council:

- Known as the Armed Forces Council in some countries (for example, in Ghana and the Gambia), the Defence Council is principally responsible for advising the President on Defence policy and acts as a mechanism for executive control and supervision of the defence forces. It is usually chaired by the President, but in a few other countries (such as Ghana) the Vice-President is the Chair. Other members include the Ministers of Foreign Defence, Foreign Affairs, and the Interior, the Chief of Defence Staff as well as the service chiefs; the President may appoint other members. The Defence Council is only advisory and in practice presidents do make defence related decisions without recourse to it, particularly in countries with weaker democratic credentials. In Botswana for instance, the Defence Council has not met for many years.

- The Police Council is principally responsible for advising the President on internal public security and safety policy. The Police Council has in some countries the Vice-President (as in Ghana), and others, the President (Nigeria) as its Chair person, while other members include the Minister of Interior, Inspector General of Police (also known as Police Commissioner in some of the countries), Attorney General, and other members whom the President may appoint.

In Francophone Africa, beyond the Council of ministers (under the authority of the prime minister) which is in theory the first level of coordination, there are no integrated processes combining external defence, internal security, policing, etc. within a single policy frame, coordinated at the national level that can be seen as comparable to the NSC. In most of the countries however, it was mentioned above (in section 3.4.1) that the Constitution sets up High Councils on the National Defence Council which are in fact rather similar to the Defence Councils that can be found in Anglophone Africa, including as regards their lack of real influence. The High Councils on National Defence are most of the time 'empty shells'.

Finally, it is important to bear in mind that key decisions, both in Anglophone and Francophone Africa are not discussed in the formal structures: informal, behindthe-scenes decision-making is often more important. 


\subsection{Role of Parliament}

In Anglophone Africa, parliamentary oversight of the security services is provided for in most of the constitutions. Under Presidential constitutions, Parliament is empowered to make laws for the regulation of the constitutional powers of the President as Commander in Chief of the security services. This parliamentary oversight is to be exercised through a number of mechanisms. As in Francophone Africa, parliaments are empowered to form select committees on particular security services for the purpose of oversight. Apart from Lesotho and Malawi, all national parliaments in Anglophone Africa have select committees responsible for oversight of the security sector. In larger parliaments, like Nigeria's and South Africa's, the Parliament has separate committees on Defence (in addition to Defence, the Senate in Nigeria has a committee for the Army, Air Force and Navy), Police (Safety and Security in South Africa) and Intelligence. In smaller parliaments, such as that of Zambia and Ghana, Defence and the Interior are combined under one committee. There are also committees on Appropriation and Public Accounts, which are meant to debate, approve and review defence, internal security and intelligence budgets. In addition, the committees have powers to conduct investigations into security matters, and to review the management of security by the executive branch as the need arises. This includes the power to summon the President, ministers or heads of the security services to Parliament to defend their actions.

The role of parliaments, as acknowledged by the constitutions, is therefore very similar in Francophone and Anglophone Africa. However, in the two sets of countries, the constitutional provisions related to parliamentarian oversight have been more than often ignored in practice.

\subsubsection{The armed forces}

\subsubsection{Organisation of the Defence Ministry}

An important difference between Francophone and Anglophone Africa is related to the division within the Ministries of Defence themselves. In almost all Anglophone countries, the Ministry of Defence (or Department of Defence) is organised along British lines and Western tradition: MoD structures in former British colonies tend to reflect a simplified version of the structures of the past, rather than the organisation of the UK MoD today. The operational commands of the forces usually work together with a civilian bureaucracy of respective ministries. At the head of the Ministry is a civilian minister appointed by the President, except for Lesotho, where the prime minister is the Minister of Defence; and Swaziland and Mauritius, where the minister is appointed by the prime minister from the parliament. ${ }^{50}$ The Ministry of Defence, which is responsible for development and implementation of national defence policy, is made up of a Defence Secretariat (defence bureaucracy) and a defence headquarters, which are headed by the (Permanent) Secretary of Defence and the Chief of Defence Staff (known as Force Commander in some countries), respectively. The Secretary is the chief

50 Botswana is the only country where there is no Ministry of Defence or defence bureaucracy. A minister in the Presidency is responsible for defence matters. 
accounting officer for the Ministry and advises the Minister of Defence on policy matters. The Chief of Defence Staff is responsible for the operational command of the armed forces and advises the minister on operational matters related to national defence. The Ministry is therefore a crucial mechanism for civil control and executive supervision of the armed forces.

\subsubsection{The Republican/Presidential Guards}

As mentioned above, presidential Guards or similar, with special responsibility for regime security, are pretty much universal in Francophone Africa.

A number of Anglophone countries have had negative experiences of the Presidential Guard in former times. In Ghana, Nkrumah established the President's Own Guard Regiment in the 1960s. Jerry Rawlings also had his own special protection units. Many other Anglophone countries have established similar units, though these have varied from country to country and period to period.

Today, formal Presidential/Republican Guards are rare in Anglophone African countries. However, in practice, a few countries, including the Gambia, Nigeria and Zimbabwe have specialised brigades within the army, known as the Brigade of Guards, which provides protection for the President. Arguably, Francophone countries differ mainly in that PGs have been more uniform and more institutionalised.

\subsubsection{The National Guard}

Contrary to Sahelian Francophone countries, the National Guard is not a common practice in Anglophone Africa. Nigeria under military rule experimented with the idea of a National Guard in the late 1980s and early 1990s, but this was quickly abandoned.

\subsubsection{The military justice}

In Anglophone countries under military rule, military justice was dispensed through the use of special military tribunals, which were ad hoc arrangements for the trial of specific offences committed by men and officers of the military. With the transition to democracy, military justice has become an important concern for security governance in terms of military discipline and the human rights of military personnel. In most Anglophone countries, the use of military tribunals for treasonable offences has become a thing of the past, though the court martial system for lesser offences is still in place. It has been observed that the most significant change has been the replacement of the president of a court martial by a judge with a law degree and experience in either criminal or military justice. In addition, judges are now more independent and less subject to the influence of military command, and accused persons can now appeal against the decision of the military court. The review of the case is done by an independent civilian court with a civilian judge presiding (Heinecken et al. 2003).

In a number of the Francophone countries (such as Mali and Senegal), military justice has also experienced significant and fundamental reform since the dawn of 
democracy. However, the reform of military justice is still a key challenge in most of the Francophone countries.

\subsubsection{Development missions for the armed forces}

Armies endowed with developmental missions are not a common practice in Anglophone Africa, contrary to Francophone Africa. In most of the Anglophone countries, the constitution typically specifies a secondary role for the armed forces to provide military aid to civil authority in periods of national emergency. An exception is Zambia where soldiers are given not only military training but also agricultural skills to assist in food production.

\subsubsection{Police forces}

It is worth noting that both in Francophone and Anglophone African countries, the police forces have been more than often instruments of political misuse. In most African countries, police forces have been treated as inferior to the military both in status and resources. Under-resourcing is a common trend in Africa and has resulted in the inability of the police to grapple with public insecurities arising from high crime rates and serious internal security threats (Anderson and Killingray 1992). The consequent loss of public confidence in the police has led to the delegitimisation of the public police and recourse to the military (resulting in a blurring of internal and external security functions) and/or to privatised sources of security and protection such as corporate security companies and vigilantes. Consequently, reforming and enhancing the operational capabilities of the police forces are top priorities in both Francophone and Anglophone countries.

However, it is paramount to address the reforms taking into account the very different organisational frameworks of policing in Francophone and Anglophone Africa. Indeed, one of the defining differences between Francophone and Anglophone states relies in large part on the kind of security forces which are responsible for the maintenance of internal order. In Francophone states, in addition to the police forces (the national and in some countries the municipal police), it was seen that the gendarmerie forces and the National Guard, besides their role in ensuring external security, are also entitled to intervene in internal order.

In Anglophone Africa, all police forces are nationally controlled (Hills 2000, 2007) i.e. they have a central command at the national level. Most police forces are therefore territorially organised into national headquarters, provincial, divisional and district commands. However, the different specialised functions of policing determine the organisation of the police. While the regular police enforce the law and work to prevent, detect and fight crime, paramilitary police concentrate on the preservation of public order. ${ }^{51}$ The paramilitary police, commonly known as the

51 Police forces in British colonies were paramilitary: post-colonial policing in Anglophone Africa has not only continued with this tradition but has witnessed an intensification of this militarisation. The practice of police under colonial rule was not only maintained, but was strengthened and converted into agents of particular regimes as well as tools for political intimidation and regime survival. The old colonial paramilitary methods of crime control were maintained in many of the new states, particularly those with a history of military rule such as Nigeria, Uganda, Eritrea and Ethiopia. 
Police Mobile Unit or the Police Mobile Force, are present in many countries, including Botswana, Malawi, Nigeria (the Police Mobile Force), Mauritius, Malawi and Lesotho. Paramilitary police forces are known as the General Service Units in Kenya, the Police Intervention Unit in the Gambia, and the Rapid Response Unit in Uganda: personnel of these specialised police are drafted from the regular police and given special training. These mobile units can be compared to the CRS of the police forces and to the mobile units of the gendarmerie in Francophone countries. In some cases, paramilitary police are deployed together with the military in internal operations during periods of disorder. In some countries, such as Nigeria, paramilitary police forces have access to hard military weapons, including helicopter gunships and armoured personnel carriers. Paramilitary policing has therefore been the hallmark of policing in Anglophone Africa, particularly when it comes to dealing with serious internal crises.

This militarisation of policing is very similar to situations in Francophone countries where the armed forces are deployed to deal with internal order disruptions without any procedures governing their deployment in aiding the civil (police) police units: in the two sets of countries, there is confusion between external and internal security functions. On the contrary, Anglophone paramilitary police forces definitely cannot be compared to the gendarmerie forces. In Anglophone countries, the military units with predominantly internal security responsibilities and/or police units equipped for crisis response or paramilitary functions do exist in a great diversity of forms. But they fundamentally differ from the Francophone gendarmeries in that the Gendarmerie is permanently constituted and institutionalised under its own statutes and operates - in principle at least - within the parameters of the legal system.

Finally, there are no counterparts to the municipal police forces that can be found in a number of Francophone countries. However, the practice of 'proximity policing' developed by the Francophone municipal police may be interestingly compared to the practice of 'community policing' developed by Anglophone police forces.

\subsubsection{The intelligence services}

As in Francophone countries, intelligence services are difficult to research in Africa, given the tradition of secrecy with which the sector is governed. However, some SSR experts have dealt thoughtfully with intelligence services in Southern Africa (Afrika and Mlombile 2001; Hutton 2007). Generally, intelligence structures in Anglophone Africa are organised around a tripod of domestic civilian intelligence, commonly known as the Security Service, an external civilian counterpart, commonly known in many countries as the National Intelligence Agency or Secret Service (South Africa); and a defence intelligence structure.

In many countries, the civilian components of intelligence are under the control of the National Security Agency in the Presidency, while defence intelligence forms part of the military organisation. Again, post-apartheid South Africa is an exception, with a portfolio Ministry for Intelligence which is responsible for civil control of the sector.

Apart from this broad categorisation, each of the security services has its own intelligence structures in many countries, such as army intelligence, police 
intelligence, etc. The proliferation of intelligence services poses a challenge for coordination in the sector, and South Africa has made the greatest effort towards overcoming this challenge by setting up the National Intelligence Coordinating Committee (NICOC).

\subsubsection{Funding provisions}

As in Francophone countries, funding for the security sector in Anglophone Africa is provided for in the overall Public Expenditure Management framework regulating the funding of the public sector. Thus, at least in theory, ministries in the security sector are funded from the national budget just as other Ministries, Departments and Agencies (MDAs). As provided in constitution and legal frameworks in all countries, the budgetary process is modelled after the liberal Western standard practice, which starts with Formulation from the Ministry of Finance (MoF) through Approval, implementation, and Reporting and Auditing, by the Auditor General. ${ }^{52}$ While the legal framework may exist in theory, what happens in practice is often entirely different: as in Francophone Africa, the real experience of Anglophone Africa shows that the civil supervision of the resources of security forces is problematic. With the exception of South Africa, adherence to the principles of public expenditure management tends to be generally low. However, in some Anglophone countries, security budgeting processes have improved in two respects:

- With the transition to democracy and constitutional rule in Anglophone countries in the 1990s, supervision of the resources of the security sector has been anchored in law and the constitution;

- Sector-wide budgets for security have been introduced in some Anglophone countries.

\subsubsection{Research on Security Sector Reform (SSR)}

Contrary to Francophone Africa, research and advocacy capacities on SSR have been increasingly networked and structured in Anglophone Africa. The most important research centres are: the ISS (Institute for Security Studies) in South Africa, the African Security Dialogue and Research (ASDR) (Ghana), the Centre for Democracy and Development (CDD) (Nigeria), the Southern African Defence and Security Management Network (SADSEM) in South Africa, the Centre for Policy Research and Dialogue (CPRD) (Ethiopia), and the Security Research and Information Centre (SRIC) (Kenya). Furthermore, a pan-African organisation, the ASSN (African Security Sector Network) is bringing together the resources and expertise of those different centres, aiming to create an African network of SSR networks. The ASSN was created out of recognition of the need to harmonise the various African organisations carrying out activities in the general area of security sector reform/transformation/governance (SSR/SST/SSG).

52 The standard liberal mechanism for public expenditure management has been well articulated by the World Bank (World Bank 1998). 


\subsubsection{Military schools and police academies in Anglophone Africa}

The most basic military school in Anglophone Africa is the Military (or Defence) Academy. This is the entry point to the military for the most junior officers as cadets for all three services, and it provides undergraduate university education and professional military development for career-orientated officers. Military academies exist in all countries in the region. Apart from the military academy, each of the three services has its own training schools to meet the specialised operational needs of its officers and men.

The Command and Staff School (CSC) is at a higher level than the military academy. This is also a joint service training institution which offers increased capacity for academic and professional training of middle-level military officers. CSCs are in a number but not all of the Anglophone countries; they usually run comparative courses for officers from other countries. At the highest level of training is the War (Defence) College, which provides defence related education, training and development services at the most strategic level. These services include war simulation, peacekeeping training, research and development. Usually it serves to prepare selected senior military officers and their civilian counterparts for high level policy, command and staff functions.

With regards to police training, there are three main types of police school in Anglophone African countries. At the lowest level are Police Training Centres for training constables. These are common within particular countries and form the entry point for new recruits. At the next level is the Police College for cadet inspectors, who are upper junior level officers. The highest level is the Police Academy, for training Cadet Assistant Superintendents. In most countries, there is only one Police Academy.

In addition, the Kofi Annan International Peacekeeping Training Centre, located in Accra (Ghana), trains and prepares the Peacekeeping Force Headquarters (Commanders and their staff - military and civilian) at the operational level of command, to operate effectively and cohesively as a National or Regional Force Headquarters or as part of an international coalition Force Headquarters in the current Peacekeeping environment. Such a school can be seen as a counterpart to the Francophone ENVR.

\section{Recommendations}

The general principles of SSR, mostly inspired by standards formulated in Anglophone environments, are no doubt relevant to Francophone Africa as well. However, for SSR programmes to be efficient in Francophone Africa, there is a need to recognise that, beyond sharing a common language, the majority of Francophone African States share a specific model from an institutional, organisational and procedural standpoint. Today, the major international actors involved in SSR acknowledge that the peculiarities of French-speaking African environments have not been sufficiently taken into account in the original conceptualisation of SSR as well as the implementation of policies on the ground. A thorough knowledge of these features is consequently necessary to ensure the 
success of reforms in Francophone Africa, both in post-conflict environments and conflict prevention strategies. In addition, SSR is a concept often overlooked by national actors in Francophone Africa; reforms in a number of Francophone countries are most often carried out sparsely, in the absence of a comprehensive and coherent approach.

The purpose of this final section is to suggest ways that are likely to improve SSR programmes implemented in Francophone African countries, taking into account their specific organisational structures and management. The overarching objective is consequently to highlight the specificities that any SSR programmer (especially within multilateral organisations such as the UN, the African Union, the European Union and the OECD) might be aware of when intervening in environments with specific traditions and backgrounds.

1 First, SSR programmers must recognise that some key challenges in undertaking SSR processes in Francophone environments are occurring directly as a result of the differences existing with Anglophone security systems: a number of security reforms - mostly technical in essence - should support the emergence of an approach of SSR, based on a thorough knowledge of the local context and sensitive to the particularities of the institutional, organisational and legal environments that can be found in Francophone Africa.

- First, it is paramount as well to capitalise - through systematic lessons learned - all the expertise accumulated by the French technical coopérants (defence, police, justice), exploring both the lessons that can be drawn from positive experiences but also - and maybe above all - from negative experiences;

- Police reform is clearly the major challenge. There is a need to develop the skills of police forces taking into account their organisational and functional specificities, particularly the divisions between national police forces, gendarmerie forces and municipal police forces. Specifically with regards to the gendarmerie forces, there is a need to envision the potentialities offered by flexible police forces that can deploy under military or civilian rule, including its implications for the size and shape of the security sector (as it might imply a smaller, more highly skilled force). It is also crucial to clarify the role of Ministries of the Interior/Internal Affairs, many of whom oversee a range of police forces (including the gendarmeries). The challenge of managing a structure that includes gendarmerie, public order police and police judiciaire services cannot be underestimated;

- As regards the armed forces, it is important to urge Francophone states to normalise the status of their Presidential Guards;

- In an important number of Francophone countries, it would also be desirable to enact legislations aimed at regulating the activities of the private security companies;

2 Second, a number of reforms - mostly aimed at fostering security governance - could be inspired by some positive experiences and practices in Anglophone countries, which have contributed to greater accountability and democratic 
governance of the security sector in accordance with the rule of law in respect of human rights. It would be advisable to adopt the following measures:

- Supporting the setting up of collegial decision-making organisations in the Francophone states, both at the strategic level (NSC-type structures) and at the operational level (Defence and police council-type structures);

- Promoting civilian control within the executive branch by urging African Francophone states to integrate further civilians into the decision-making bodies of the Ministries of Defence (including promoting civilian control within the executive branch by setting up a civilian counterpart to the CEMA (Chief of Defence Staff));

- Setting up structures inspired by the South African National Intelligence Coordinating Committee (NICOC) to oversee the activities of the intelligence services;

- Anchoring the supervision of the resources of the security sector in law and the constitution and developing a sector wide budget for security, as has been done in some Anglophone African countries. There is also a need to assess the number of people employed in the defence sector accurately. This is quite important, as it has budgetary implications as well as oversight implications.

3 Finally, to harmonise best practices and security governance on the African continent as a whole, there is clearly a dire need to develop interactions between Anglophone and Francophone African countries by:

- Developing common trainings for the armed and security forces of Anglophone and Francophone countries, particularly within training schools with a regional or continental vocation;

- Developing good practice exchanges between African Francophone countries on the one hand, but also between Francophone and Anglophone countries which can be considered as having a good record in terms of security governance (for instance, by Organising at the AU level good practice exchanges between practitioners);

- Supporting the intensification of interaction between African parliamentarians across linguistic boundaries to enable them to enjoy the prerogatives they are endowed with by the Constitutions. In order to strengthen the supervision and oversight role of Francophone Parliaments as well as Anglophone Parliaments, there is a need to conceptualise and implement programmes that aim to bring together, on a sub-regional (REC) and cross-regional basis, training seminars and workshops for parliamentarians with various and uneven experiences in SSR of parliamentary oversight (best practice exchanges);

- Encouraging the Africanisation of African expertise and supporting the emergence of a pan-African SSR expertise by encouraging the integration of Francophone African research and assessment capacities into the framework of the existing strong centres and networks which have been working on SSRrelated issues for 20 years or so in Anglophone African countries. 


\section{Conclusion}

The time is ripe to share and build upon the experience of both Francophone and Anglophone Africa within shared policy frameworks/concerns, either by extending the theory and practice of SSR to Francophone countries, or through other less intrusive forms of experience sharing. Yet institutional variations matter and have to be understood and built into policy and practice on SSR. The general principles of SSR are without doubt relevant to Francophone Africa as well. However, for SSR programmes to be efficient in Francophone Africa, a thorough knowledge of institutional and organisational features of Francophone African countries is necessary to ensure the success of security reforms, both in post-conflict environments and in conflict prevention strategies. 


\section{Annex: Military schools in Francophone Africa}

\begin{tabular}{|c|c|c|c|}
\hline Country & Town & ENVR & Acronym \\
\hline Senegal & Thies & $\begin{array}{l}\text { Infantry Application School } \\
\text { (Ecole d'Application de } \\
\text { l'Infanterie) }\end{array}$ & EAl \\
\hline Senegal & Thies & $\begin{array}{l}\text { Active Officers National School } \\
\text { (Ecole nationale des Officiers } \\
\text { d'Active) }\end{array}$ & ENOA \\
\hline Senegal & Oukam & $\begin{array}{l}\text { Mobile Gendarmerie } \\
\text { Improvement Centre (Centre } \\
\text { de perfectionnement de la } \\
\text { gendarmerie mobile) }\end{array}$ & CPGM \\
\hline Mali & Koulikouro & $\begin{array}{l}\text { Military Administration } \\
\text { School (Ecole militaire } \\
\text { d'administration) }\end{array}$ & EMA \\
\hline Mali & Koulikouro & $\begin{array}{l}\text { General Staff School (Ecole } \\
\text { d'état-major) }\end{array}$ & EEM \\
\hline Mali & Bamako & $\begin{array}{l}\text { Peacekeeping School (Ecole } \\
\text { de maintien de la paix) }\end{array}$ & EMP \\
\hline Gabon & Libreville & $\begin{array}{l}\text { General Staff School (Ecole } \\
\text { d'état-major) }\end{array}$ & EEM \\
\hline Benin & Ouidah & $\begin{array}{l}\text { Demining and Depollution } \\
\text { Centre (Centre de } \\
\text { perfectionnement aux } \\
\text { techniques de déminage et } \\
\text { de dépollution) }\end{array}$ & CPADD \\
\hline Benin & Porto-Novo & $\begin{array}{l}\text { 'Police judiciaire' Improvement } \\
\text { Centre (Centre de } \\
\text { perfectionnement de la police } \\
\text { judiciaire) }\end{array}$ & CPPJ \\
\hline Niger & Niamey & $\begin{array}{l}\text { Paramedical Staff School } \\
\text { (Ecole des personnels } \\
\text { paramédicaux) }\end{array}$ & EPPAN \\
\hline Togo & Lomé & $\begin{array}{l}\text { Health Service School (Ecole } \\
\text { du service de santé) }\end{array}$ & ESSAL \\
\hline Burkina Faso & Ouagadougou & $\begin{array}{l}\text { Military Technical School } \\
\text { (Ecole militaire technique) }\end{array}$ & EMTO \\
\hline Cameroon & Awae & $\begin{array}{l}\text { Law Enforcement Improvement } \\
\text { Centre (Centre de } \\
\text { perfectionnement aux } \\
\text { techniques de maintien de } \\
\text { l'ordre) to become EIFORCES }\end{array}$ & $\begin{array}{l}\text { CPTMO/ } \\
\text { EIFORCES }\end{array}$ \\
\hline Cameroon & Garoua & $\begin{array}{l}\text { Aeronaval Training Centre } \\
\text { (Pôle aéronautique à vocation } \\
\text { régionale) }\end{array}$ & PANVR \\
\hline
\end{tabular}




\section{References: Security systems in Francophone Africa}

Abdourahmane, B.I. and Crouzel, I. (2004) A Comparison of the Budget Processes in France and Francophone Africa, Cape Town, SA: IDASA

Agokla, K. (2010) 'Le Cadre Institutionnel et le Système de Sécurité au Togo', in K. Agokla, N. Bagayoko and B.N'Diaye (eds), La Réforme des Système de Sécurité et de Justice en Afrique Francophone, Paris: OIF

Ango Ela, P. (1996) 'La Coopération Militaire Franco-africaine', Relations Internationales et Stratégiques 23: 178-86

Balmond, L. (1998) 'Les Interventions Militaires Françaises en Afrique', Centre d'étude et de Recherche sur la Défense et la Sécurité, Collection Travaux et Recherches de l'Institut de Droit de la Paix et du Développement de l'Université de Nice-Sophia Antipolis, Paris: Editions Pédone

Barillot, B. (1993) 'L'Afrique Sous Tutelle Militaire Française', Damoclès, Lyon: CDRPC

Bayley, D.H. (1985) Patterns of Policing: A Comparative International Analysis, New Brunswick, New Jersey: Rutgers University Press

Bryden A.; N'Diaye, B. and Olonisakin, F. (dir. publ.) (2008) Gouvernance du Secteur de la Sécurité en Afrique de l'Ouest: Les Défis à Relever, Zürich and Berlin: Lit Verlag

Cabanis, A. and Martin, L.M. (1998a) Les Constitutions d'Afrique Francophone: Evolutions Récentes, Paris: Khartala

Cabanis, A. and Martin, M.L. (1998b) 'Armée et Pouvoir dans les Nouvelles Constitutions d'Afrique Francophone', Revue Juridique et Politique, Indépendance et Coopération 3.52

Chaigneau, P. (1984) La Politique Militaire de la France en Afrique, Paris: Centre des Hautes Etudes sur l'Afrique et l'Asie Modernes (CHEAM)

Charbonneau, B. (2008) France and the New Imperialism: Security Policy in SubSaharan Africa, Aldershot UK: Ashgate Publishing

Clark, J.F. and Gardinar, D. (1996) Political Reform in Francophone Africa, Boulder: Westview Press

Daloz, J.-P. and Quentin, P. (1997) Transitions Démocratiques Africaines, Paris: Khartala

Das, D.K. and Palmiotto, M. (2006) World Police Encyclopaedia, New York/London: Routledge

Du Bois de Gaudusson, J.; Conac G. and Desouches, C. (eds) (1997) Les Constitutions Africaines Publiées en Langue Française, T. 1 Algérie, Bénin, Burkina Faso, Burundi, Cameroun, Cap-Vert, Comores, Congo, Côte d'Ivoire, 
Djibouti, Egypte, Gabon, Guinée, Madagascar, Paris: La Documentation Française, Brussels: Bruylant

Dumoulin, A. (1997) 'La France Militaire et l'Afrique', Groupe de Recherche et d'Information sur la Paix et la Sécurité (GRIP), Brussels: Editions Complexe

Faupin, A. (2005) Providing Security: The Division of Labour, Armed Force, Gendarmerie and Police, DCAF Working Paper 156, Geneva: Geneva Centre for the Democratic Control of the Armed Forces

Franceschi, P. (2007) 'Plaidoyer pour la Création de Forces de Gendarmeries Africaines', Défense Nationale et Sécurité Collective 10: 179-86

_ (2006) 'La Régionalisation du Maintien de la Paix en Afrique: Une Evolution des Rapports entre les Gendarmeries Africaines', Revue de la Gendarmerie Nationale 220

Fogue, A. (2007) 'Approche Géopolitique des coupeurs de route au Cameroun', Revue Enjeux 33

Gounin, Y. (2009) La France en Afrique: Le Combat des Anciens et des Modernes, Paris: De Boeck

Gregory, S. (2000) 'The French Military in Africa: Past and Present', African Affairs 99.396: 435-48

Kurian, G.T. (2006) World Encyclopaedia of Police Forces and Correctional Systems, 2nd edn, Detroit: Thomson Gale

Lavroff, D.G. (1984) 'La Constitutionnalisation des Régimes Militaires Africains', in J.L. Seurin, Le Constitutionnalisme Aujourd'hui, Paris: Economica: 200-13

_ (1976) 'Les Influences de la Période Coloniale sur l'Avènement de Régimes Militaires en Afrique Noire', Journal of African Law 20.2: 100-6

Leymarie, Philippe (2004) 'En Afrique, une Nouvelle Génération de Chiens de Garde', Le Monde Diplomatique, November

Luckham R. (1982) 'Le Militarisme Français en Afrique', Politique Africaine: 95-110

Lutterbeck, D. (2004) 'Between Police and Military: The New Security Agenda and the Rise of Gendarmeries', Cooperation and Conflict: Journal of Nordic International Studies Association 39.1

Martin, M.L. (1976) La Militarisation des Systèmes Politiques Africains. Une Tentative d'Interprétation, Gherbrooke, Québec: Editions Naaman

National Democratic Institute (1999) The Role of the Legislature in Defence and National Security Issues, Seminar Report, 19-22 April, Dakar, Senegal

- (1997) Report of the Civil-Military Relations Assessment Mission: West and Central Africa, 18 March to 10 April

N'Diaye B. (2007) 'Security 'A la Française': Francophone Africa's Security Sector Non-Transformation', draft paper 
Observatoire des Fonctions Publiques Africaines (OFPA) (1995) Recueil des Statuts Particuliers des Fonctions Publiques Africaines, Vol. II, Cotonou : OFPA Observatoire Permanent de la Coopération Française (2002) Rapport 2002, Paris: Khartala

— (1996) Rapport 1996, Paris: Khartala

Pabanel, J.P. (1984) Les Coups d'Etat en Afrique Noire, Paris: L'Harmattan Petiteville, F. (1996) 'Quatre Décennies de "Coopération Franco-africaine": Usages et Usures d'un Clientélisme', Revue Etudes Internationales 27.3

- (1996) Rapport de l'Observatoire Permanent de la Coopération Française 1996 et 1997, Paris: Desclée de Brouwer

Revue Frères d'armes (2009), Dossier Gendarmerie en Cooperation 261, www.diplomatie.gouv.fr/fr/actions-france_830/defense-securite_9035/cooperationsecurite-defense_9037/revue-freres-armes_12582/freres-armes-261-dossiersecurite-interieure-gendarmerie_19612/index.html (accessed 20 April 2010)

Roitman, J. (2004) Fiscal Disobedience: An Anthropology of Economic Regulation in Central Africa, Princeton: Princeton University Press

Roussillon, H. (1995) Les Nouvelles Constitutions Africaines: La Transition Démocratique, Toulouse: Presse de l'Institut d'Etudes politiques de Toulouse

Sangaré, N. (2006) 'Mali', in E. Hutchful and W. Omitoogun (eds), Budgeting for the Military Sector in Africa: The Processes and Mechanisms of Control, New York: SIPRI (Stockholm International Peace Research Institute), Oxford University Press

Smith, S. (1996) 'Dessine-moi un Caméléon. L'Interventionnisme Militaire de la France en Afrique', Défense, Paris: Institut des Hautes Etudes de la Défense Nationale

Toulabor, C. (2005) Les Forces Armées Togolaises et le Dispositif Sécuritaire de Contrôle (1\&2), Articles sur la Toile à l'adresse, www.ufctogo.com/Les-forcesarmees-togolaises-et-le-1082.html (accessed 8 March 2010)

UNREC (2008) (African Security Sector Reform Programme - ASSEREP), Report on Security Sector Reform in Togo, January 2007-December 2008

Vasset, P. (1997) 'The Myth of Military Aid: The Case of French Military Cooperation in Africa', SAIS Review 17.2: 165-80

Verschave, F.X. (1998) La Françafrique: Le Plus Long Scandale de la République, Paris: Stock

Wauthier, C. (1995) Quatre Présidents et l'Afrique, Paris: Seuil, Collection l'Histoire Immédiate

Yaya, M. (2004) Public Expenditure Management in Francophone Africa: A Crosscountry Analysis, IMF Working Paper 04/42, Washington: IMF 


\section{References: Security systems in Anglophone Africa}

Aboagye, F. and Rupiya, M. (2005) 'Enhancing Post-Conflict Democratic Governance Through Effective Security Sector Reform in Liberia', in F. Aboagye and A. Bah (eds), A Tortuous Road to Peace, Pretoria: Institute for Security Studies: $249-80$

Afrika, S. and Mlombile, S. (2001) 'Transforming the Intelligence Services: Some Reflections on the South African Experience', paper for International Center for Criminal Justice, Boston: Harvard University. www.law.harvard.edu/programs/criminal-justice/south-africa.pdf (accessed 16 February 2010)

Anderson, D.M. and Killingray, D. (1992) Policing and Decolonisation:

Nationalism, Politics and the Police, 1917-1965, Manchester: Manchester University Press

Cawthra, G. and Luckham, R. (eds) (2003) Governing Insecurity: Democratic Control of Military and Security Establishments in Transitional Democracies, London and New York: Zed Books

Ebo, A. (2005) The Challenges and Opportunities of Security Sector Reform in Post-Conflict Liberia, Geneva Centre for Democratic Control of Armed Forces (DCAF) Occasional Paper 9, Geneva: DCAF

Edigheji, O. (2005) A Democratic Developmental State in Africa?, Research Report 105, Johannesburg: Centre for Policy Studies

Hughes, G. (2007) South Africa Defence Transformation: A Project Still in Progress, Cranfield CSSM Case Study Series 11/07, Cranfield: Centre for Security Sector Management

Gbla, O. (2007) 'Security Sector Reform in Sierra Leone', in L. Le Roux and Y. Kidane (eds), Challenges to Security Sector Reform in the Horn of Africa, ISS Monograph Series 135, Johannesburg

Heinecken, L.; Nel, M. and Janse van Vuuren, J. (2003) 'Military Discipline: Where are we Going Wrong?', Strategic Review for Southern Africa

Hills, A. (2007) 'Police Commissioners, Presidents and the Governance of Security', Journal of Modern African Studies 45.3

_ (2000) Policing Africa: Internal Security and the Limits of Liberalisation, Boulder: Lynne Rienner

Howe, H.M. (2000) Ambiguous Order: Military Forces in African States, London: Lynne Rienner

Hutton, L. (2007) Looking Beneath the Cloak: An Analysis of Intelligence Governance in South Africa, ISS Paper 154, Pretoria: Institute for Security Studies 
Ibrahim, J. (2003) Democratic Transition in Anglophone West Africa, Dakar: Council for the Development of Economic and Social Research in Africa (CODESRIA)

National Democratic Institute (1999) The Role of the Legislature in Defence and National Security Issues, Seminar Report, 19-22 April, Dakar, Senegal

National Democratic Institute (1997) Report of the Civil-Military Relations Assessment Mission, West and Central Africa, Dakar, Senegal

Poverty Reduction and Economic Management Network (1998) Public Expenditure Management Handbook, World Bank: Washington DC

Rouvez, A. (1994) Disconsolate Empires: French, British and Belgian Military Involvement in Post-Colonial Sub-Saharan Africa, Lanham, Maryland: University Press of America, Inc.

Rupiya, M. (ed.) (2005) Evolutions and Revolutions: A Contemporary History of Militaries in Southern Africa, Pretoria: Institute for Security Studies (ISS)

Somerville, K. (1990) Foreign Military Intervention in Africa, London: Pinter Publishers Ltd

World Bank (1998) Public Expenditure Management Handbook, Poverty Reduction and Economic Management Network, Washington DC: World Bank 
IDS RESEARCH REPORT 64 